\title{
Do pensions foster education? An empirical perspective
}

\begin{abstract}
The paper examines the effect of population ageing on public education spending. On the one hand, ageing is expected to have a negative effect on education, as an increasing number of retirees results in "intergenerational conflict" and, hence, the condemnation of education expenditure. On the other hand, ageing, in combination with pay-as-you-go pension systems, offers incentives for the working-age generation to invest in the public education of the young in order to "reap" the benefits (that is, higher income tax/contributions) of their greater future productivity. Empirical evidence derived from the application of a fixed effects approach to panel data for OECD countries shows that the increasing share of elderly people has a non-linear effect on education spending. This indicates a certain degree of intergenerational conflict. Nevertheless, we find that future population ageing, which reinforces the mechanism linking public education and pensions, reflects positively on education expenditure. Furthermore, by disaggregating total education expenditure by educational levels, we observe that this effect is led by levels of non-compulsory education, probably as a reflection of the direct connection to labor productivity.

Keywords: Education Spending, Pay-As-You-Go Pension System, Population Ageing, Intergenerational Conflict, Voting.

JEL Classification: D72, H52, H55, I22, J11.
\end{abstract}

\section{Introduction}

The welfare state has gradually extended its action from mere monetary transfers for poverty reduction to broader welfare programs, including the provision of basic social goods (education and health), and to income substitution programs, including pensions, with a high insurance component. Interestingly, this process can be said to have led to the gradual substitution of private intergenerational transfers from the public sphere. Indeed, in such instances, government intervention extends beyond intra-generational redistribution to constitute intergenerational redistribution. Today, two of the main policies of OECD countries are public education and pensions, two polices that directly impact the extremes of dependency (children and the elderly). More specifically, the size of public pensions in OECD countries in 2012 stood at $7.6 \%$ of GDP, while expenditure on public education represented on average $5.5 \%$ of GDP. ${ }^{1}$

\footnotetext{
${ }^{1}$ For data sources, see Table 9, Appendix B.
} 
Parallel to this, we have seen the unfolding of the demographic transition. Population ageing has become an issue of growing concern, especially as the generation of "baby boomers" reach retirement age, putting considerable pressure on current pay-as-you-go (PAYG) pension systems. In 2012, the average old-age dependency ratio for the OECD countries was $22.4 \%$, but this figure is expected to rise to $43.4 \%$ by 2040 . The forces behind population ageing are declining fertility rates - following on from the post-war "baby boom" - and increased life expectancy. Among other things, the latter is a result of better quality services due to technological progress in the healthcare system, while the former results from the increasing opportunity cost for women of having children in developed economies. $^{2}$

Both processes - demographic change and the extension of the welfare state - seem to be related, as shown by the convergence of both strands of the literature. This relationship between economic and demographic variables is mediated either by a household's reactions to exogenous changes and/or changes in preferences and social norms. ${ }^{3}$ Hence, the study of intergenerational transfers means considering, more or less explicitly, hypotheses about the motives for private transfers and government intervention, which can range from forward (towards the young) and backward (towards the elderly) altruism to strategic behavior or, in line with recent studies of endogenous preferences, they can be due to reciprocity. ${ }^{4}$ The political economy literature also converges with the literature on intergenerational transfers and population change by investigating the link between forward and backward intergenerational transfers (henceforth, FITs and BITs, respectively) in the absence of altruism. This link is quite intuitively present in the family but to a lesser extent in government action.

Scholars have previously examined the existence of a link between public FITs (e.g. education) and BITs (e.g. pensions) by addressing the question as to why selfish generations choose to transfer public resources to future generations. The main reason seems to lie in the fact that markets and intra-family reallocations are failing to achieve certain important social goals by providing nonoptimal investments in human capital for the young and pensions for the old (Becker and Murphy 1988). Hence, governments have to step in and correct that failure by creating a social contract between generations. According to the terms of which, the older generations invest economic resources in the younger generations in expectation of future benefits. Public intergenerational contracts, in which generations link FITs (e.g. education) to BITs (e.g. pensions) can achieve an optimal and sustainable allocation of economic resources (Rangel 2003; Boldrin and Montes 2005). ${ }^{5}$ More specif-

\footnotetext{
${ }^{2}$ According to Galor and Weil (1996), this is brought about by the higher increase in female wages with respect to household income. Other potential channels include the increase in human capital investment per child and the quantity-quality trade-off à la Becker (Becker, Murphy, and Tamura 1990; Galor and Weil 2000).

${ }^{3}$ Doepke and Tertilt (2016) recognize the need to incorporate changes in family structure in dynamic macroeconomic models.

${ }^{4}$ See Michel, Thibault, and Vidal (2006) for a survey on forward and backward altruism in the context of neoclassical growth models; Laferrère and Wolff (2006) for a survey on the motives for private transfers; and Fehr and Schmidt (2006) for a detailed survey on altruism and endogenous preferences (i.e. other-regarding preferences).

${ }^{5}$ Rangel (2003) examines the possibility of sustaining a system of public FITs and BITs using sub-game perfect equilibrium in seeking to determine the ability of non-market intergenerational arrangements to invest optimally in FITs and BITs. With the help of simple trigger strategies in a repeated voting setting, he concludes that the provision of education for the younger cohort is optimal and sustained only when it is linked to sufficiently large transfers to the older cohort. This theory is tested empirically in Michailidis and Patxot (2018). Also, Boldrin and Montes (2005)
} 
ically, the design of the PAYG pension system - pay "now" and receive "tomorrow" - creates the appropriate incentives to invest in public education (Pogue and Sgontz 1977). The working age generations are willing to pay for public education only if they can "reap" gains of higher productivity in the future in terms of higher, taxable income (Konrad 1995), social security contributions (Kemnitz 2000; Gradstein and Kaganovich 2004) and higher returns on savings (Boldrin 1992; Boldrin and Rustichini 2000). ${ }^{6}$.

However, the demographic transition is predicted to have a significant impact on the aforementioned intergenerational contract and, hence, on the link between pensions and education. ${ }^{7}$ According to the median voter theorem, governments implement the distribution of public funds that is preferred by the median voter (Downs 1957) and as the median voter becomes older - due to population ageing - the political clout of the elderly seems set to grow. In turn, the increasing political power of the elderly transforms the allocation of public resources, shifting more resources towards the older cohorts (e.g. for pensions) and fewer to the younger cohorts (e.g. for education) (Browning 1975). ${ }^{8}$ In the context of a limited fiscal budget, this reallocation of public funds might trigger a "struggle" for fiscal resources between the young and elderly, the so-called "intergenerational conflict" hypothesis.

Despite this, a number of theoretical studies show that a positive link between public pensions and education is actually strengthened as a population ages. Lancia and Russo (2016) argue that adults support education only if they can ensure that they will be able to extract political rent in form of pensions in the future. Hence, the strategic role of human capital is stronger when the political power of elderly is larger and the forward looking adults support public education policy as they are democratically entitled to claim a share of the produced human capital of future generations Kemnitz (2000), using an overlapping generations model - in which the determination of intergenerational transfers is decided in a context of representative democracy - shows that the demographic transition achieves a better backward (pensions) and forward (education) redistribution of public funds. ${ }^{9}$ This study highlights the impact that the political influence of the working population has on the political power of retirees. As a result, population ageing, accompanied by the specific structure of the PAYG pension system, stimulates the working generation to invest in education so as to provide future pension benefits for themselves. Gradstein and Kaganovich (2004) reach similar conclusions, albeit based on a slightly different intuition. They state that as the elderly population grows there should be two antithetical effects (direct and indirect) on public education expenditure: on the one hand,

stress that only financing public education is not sufficient to restore economic efficiency, because in order to do so an additional intergenerational trade arrangement is needed.

${ }^{6}$ The main incentives for investing in education are more closely related to the middle-aged generation. Nevertheless, the elderly might choose to reallocate public resources towards the education of the young because of the positive impact that the quality of schooling might have on property values (housing prices) (Poterba 1998; Harris, Evans, and Schwab 2001; Brunner and Balsdon 2004)

${ }^{7}$ Moreover, according to previous findings, the impact of ageing on economic growth is sensitive to the forms of the social transmission of human capital (Choi and Shin 2015). The authors findd that the decrease in GDP and per-capita GDP in Korea would have been more severe if there were no increase in the investment in human capital.

${ }^{8}$ In this context, Jäger and Schmidt (2016) find that population ageing reduces the overall support for public investment. The authors relate this finding to differences in discount rates by age groups (the elderly discount future payoffs more heavily than working-age people.

${ }^{9}$ As shown in Appendix B Figure 4, parallel to population ageing, there is an increasing trend for education and pension spending per student and retiree, respectively. 
the direct effect of the aforementioned intergenerational conflict; and, on the other, the fact that there are working-age agents who foresee that they are going to live longer because of the increase in longevity. These agents also realize that the increased number of retirees makes the PAYG pension system less generous in terms of spending per retiree. Having anticipated these outcomes, they react by investing more in education in the current period in order to take advantage of the future higher productivity of these young people (i.e. an indirect effect). ${ }^{10}$ In this way, working-age agents pursue an increase in future tax revenues and endeavor to ensure a higher return on their savings in order to deal with the increased fiscal needs of a prolonged retirement. The authors find that, even in the absence of altruistic linkages, the indirect effect is stronger than the direct and that, therefore, the ageing process might have a positive impact on the amount spent on education.

The main objective of this paper is to undertake an empirical examination of both the direct and indirect effects of demographic change on current public education spending. To the best of our knowledge, no empirical study has yet to test for the two effects proposed by the aforementioned theoretical studies (Kemnitz 2000; Gradstein and Kaganovich 2004). This is what we attempt here, and what can be considered as this study's value added to the existing literature.

In the existing empirical literature, most studies focus on testing the direct effect (intergenerational conflict) and rely on data from a single country. In the case of the U.S., Poterba (1997) argues that the effect of gerontocracy on education outlay per child is negative. However, Ladd and Murray (2001) question the approach of Poterba (1997) on the grounds that the use of local government as opposed to state-level data may weaken the negative effect of the share of the elderly on education spending per student or even make it insignificant. Harris, Evans, and Schwab (2001) try to reconcile these two studies using a panel data set at the school district level. While they find a negative effect of a growing elderly population, the magnitude of the impact is far more moderate than that reported for the state-level model of Poterba (1997). Subsequently, Grob and Wolter (2007) and Borge and Ratts $\varnothing$ (2008) have used state-level data for the Swiss Cantons and local governments in Denmark, respectively. Both studies find evidence in favor of the intergenerational conflict hypothesis. ${ }^{11}$ However, as Krieger and Ruhose (2013) show, there is only partial evidence for this when the hypothesis is examined using the panel data of OECD countries. ${ }^{12}$

Using an enhanced panel data set for OECD countries, we examine the effects of the demographic transition on education spending: that is, the direct effect caused by intergenerational conflict and the indirect effect caused by the positive link between pensions and education. Our results show that current population ageing appears to be negatively related to education expenditure, although it seems to be dependent on the level of total pension spending, indicating a "struggle" for public resources - between generations - in times of fiscal scarcity. However, we obtain a positive impact on

\footnotetext{
${ }^{10}$ This mechanism finds some empirical confirmation in Cattaneo and Wolter (2009). The authors suggest that those aged between 30 and 50 are more likely to support an increase in education expenditure than are those above the age of 60 .

${ }^{11}$ In the case of the Swiss Cantons, these results are reinforced by Cattaneo and Wolter (2009). According to their survey-based evidence, the elderly are less willing to support an increase in education expenditure or an increase in taxes to finance education. Similar findings on the negative preferences of elderly on education spending are obtained by ?) and Hess, Nauman, and Steinkopf (2017) using data on several OECD and EU countries, respectively.

${ }^{12}$ Busemeyer (2007) and Morales, Fortes, and Guarnido (2013) also conduct a cross-national study, although their analysis is focused on the main determinants of education expenditure rather than on the impact of the demographic transition.
} 
both the size (total spending) and generosity (spending per student) of the education system, when we consider projected population ageing. Finally, decomposing total education spending by level of education, we find that only the non-mandatory educational levels benefit from future population ageing. This could be due primarily to the fact that there is space for political intervention in favor of enhancing future labor productivity.

The remainder of this paper proceeds as follows. Section 2 presents the data and methodology. Section 3 is devoted to a replication of past studies. In section 4 we revisit the intergenerational conflict hypothesis. Section 5 and 6 analyze the impact of projected population ageing on total education expenditure and on spending per level of education, respectively. In the last section we provide our conclusions, discuss some possible policy implications and suggest topics for future research.

\section{Data and Methodology}

\subsection{Data}

We use panel data for 31 OECD countries and yearly observations over the period 1996-2015. ${ }^{13}$ The choice of the annual base analysis is partially justified by the empirical evidence provided in Appendix B Figure 5. This figure shows that education spending fluctuates on a yearly basis in contrast with pensions that vary over a longer period, which is necessary for pension reform. Also, according to De La Croix and Doepke (2009) is a common sense to think of a government that adjusts education budget on a yearly basis. In addition, the choice of the time period of our sample, apart from the current population ageing (1996-2017) ${ }^{14}$, also allows us to capture the retirement of the "baby boomers" (2016-2035) - generations born from 1946-1964 - when we use as a proxy variable the future old dependency ratio that is projected 18 years in the future (2018-2035), see Figure 1.

\footnotetext{
${ }^{13}$ Australia, Austria, Belgium, Canada, Czech Republic, Denmark, Estonia, Finland, France, Germany, Greece, Hungary, Iceland, Ireland, Israel, Italy, Japan, South Korea, Mexico, Netherlands, New Zealand, Norway, Poland, Portugal, Slovak Republic, Slovenia, Spain, Sweden, Switzerland, U.K., U.S.

${ }^{14}$ We use the observed data on ODR for 2016 and 2017 instead of using the projected one although there are no significant differences. Moreover, when we run the regressions using the projected data (for 2016 and 2017) there are no significant changes (results available upon request).
} 
Figure 1: Current and future population ageing on average of 31 OECD countries

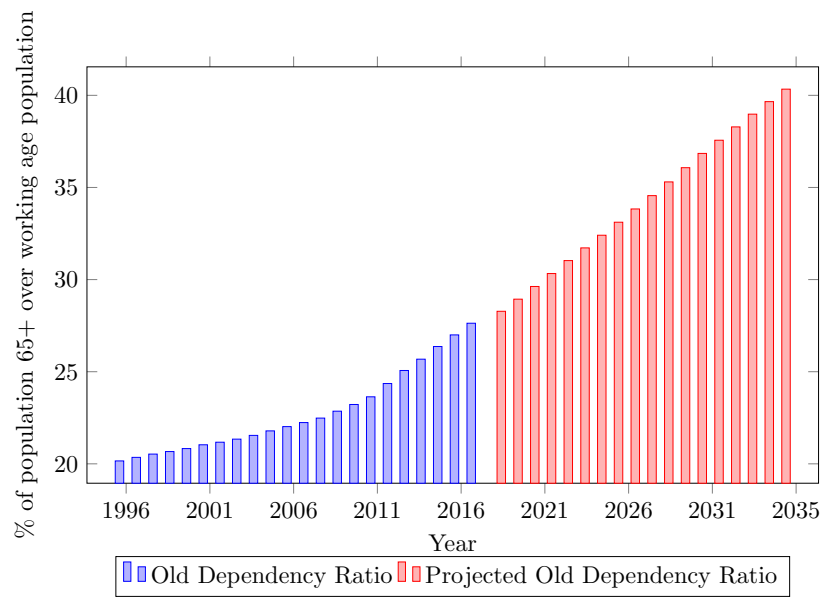

In Table 1, we summarize the main descriptive statistics of the variables that we use in our model. ${ }^{15}$ The first two variables according to Table 1 are used as dependent variables and represent the total education spending or the size of the education system as a percentage of GDP (TES) and per-student spending (ESPS) or the generosity of the education system, respectively. ${ }^{16}$ A closer look at Table 1 and Table 8 shows that, for both total education and per-student spending, the differences between countries are bigger than the differences within countries (over years). The next two variables are the total (TPS) and per-retiree pension spending (PSPR). We incorporate the pension outlays in order to check the potential link with education expenditure.

\footnotetext{
15 Definitions and sources of the variables can be found in Table 9 in the Appendix B.

${ }^{16}$ Total general (local, regional and central) government expenditure on education (current, capital, and transfers), expressed as a percentage of GDP. It includes expenditure funded by transfers from international sources to government.
} 


\section{Table 1: Descriptive Statistics}

A. Education Spending-Dependent Variables

\begin{tabular}{llrrrr}
\hline & N & mean & sd & min & max \\
\hline TES: Total Education Spending (\% of GDP) & 609 & 5.371 & 1.1699 & 2.9887 & 8.8069 \\
ESPS: Education Spending per Student & 606 & 6.3954 & 3.2454 & .6691 & 19.3315 \\
PPES: Pre-Primary Education Spending (\% of GDP) & 471 & .4445 & .2152 & .0291 & 1.3437 \\
PES: Primary Education Spending (\% of GDP) & 473 & 1.4254 & .4419 & .5381 & 2.6816 \\
SES: Secondary Education Spending (\% of GDP) & 479 & 2.0592 & .423 & .9617 & 3.0541 \\
TERES: Tertiary Education Spending (\% of GDP) & 503 & 1.2487 & .4326 & .3059 & 2.6367 \\
\hline
\end{tabular}

B. Retirement Spending Variables

\begin{tabular}{lrrrrrr}
\hline & N & mean & sd & min & max & \\
\hline TPS: Total Pension Spending (\% GDP) & 554 & 6.8624 & 2.8467 & .5 & 13.72 \\
PSPR: Pension Spending per Retiree & 554 & 13.2055 & 5.7301 & .8376 & 32.3935 & \\
\hline
\end{tabular}

C. Demographic Variables

\begin{tabular}{|c|c|c|c|c|c|}
\hline & $\mathbf{N}$ & mean & sd & $\min$ & $\max$ \\
\hline PRODR: Projected Old Dependency Ratio & 620 & 33.5752 & 7.8432 & 10.6217 & 58.9743 \\
\hline ODR: Old Dependency Ratio & 620 & 22.36731 & 5.2894 & 7.9619 & 44.1976 \\
\hline PopEduc: Population of the Official Age for Education & 619 & 9.7829 & 16.7128 & .0932 & 89.6784 \\
\hline Fertility rate & 620 & 1.6626 & .3891 & 1.08 & 3.09 \\
\hline $\begin{array}{l}\text { ppoap: Population of the official age for Pre-Primary Ed- } \\
\text { ucation }\end{array}$ & 619 & 1.2114 & 2.2732 & .0124 & 12.333 \\
\hline poap: Population of the official age for Primary Education & 619 & 2.6474 & 4.8474 & .0297 & 24.9838 \\
\hline $\begin{array}{l}\text { soap: Population of the official age for Secondary Educa- } \\
\text { tion }\end{array}$ & 619 & 3.0619 & 5.023 & .0294 & 26.0222 \\
\hline toap: Population of the official age for Tertiary Education & 618 & 2.4636 & 4.1050 & .0208 & 22.5103 \\
\hline
\end{tabular}

D. Macroeconomic and Fiscal Variables

\begin{tabular}{|c|c|c|c|c|c|}
\hline & $\mathbf{N}$ & mean & sd & $\min$ & $\max$ \\
\hline GDPpc: GDP per capita & 620 & 30.2911 & 11.2317 & 6.917 & 68.7794 \\
\hline RGDPgr: Real GDP per capita & 620 & 2.5012 & 3.0155 & -14.7 & 25.5572 \\
\hline TaxRev: Tax Revenues & 620 & 34.3952 & 7.0032 & 13.754 & 49.508 \\
\hline TotSocExp: Total Social Expenditures & 608 & 20.6103 & 5.6777 & 3.4 & 31.938 \\
\hline SocExp: Social Expenditures & 554 & 13.5204 & 3.7088 & 2.4 & 21.9 \\
\hline
\end{tabular}

E. Institutional and Political Variables

\begin{tabular}{lrrrrrr}
\hline & N & mean & sd & min & max \\
\hline MYS: Mean Years of Schooling & 620 & 11.0259 & 1.5049 & 6.4723 & 14.1 \\
GI: Globalization Index & 620 & 80.6224 & 8.5111 & 54.3113 & 92.3716 \\
VAI: Voice and Accountability Index & 620 & 1.2119 & .3603 & -.0791 & 1.8263 \\
EFI: Economic Freedom Index & 620 & 70.0617 & 6.7921 & 50.4 & 83.1 & 1 \\
Left & 620 & .3983 & .4899 & 0 & 1 \\
\hline
\end{tabular}

Note: Data on Public Pensions is not available after 2013. PSPR, ESPS and GDPpc are measured in $\$ 1000$.

PopEduc, ppoap, poap soap and toap are measured in \$1000000. SocExp does not include pensions spending.

The demographic variables (PRODR, ODR, PopEduc, Fertility) describe the projected old dependency ratio 17 years in the future (2018-2035), the current old dependency ratio (1996-2017), the population of official age for education and the fertility rate, respectively. First, the projected old dependency ratio is employed to examine the effect that future ageing has on current education 
expenditure. The underlying hypothesis here is that the working-age cohort, realizing the forthcoming demographic crisis, chooses to invest in education in order to preserve its pension benefits in the future. Therefore, it is expected that the effect of the projected old dependency ratio will have a positive effect on education spending. Second, the current old dependency ratio is used to test the hypothesis that there is a conflict over public resources between generations because of the increasing political power of the elderly. Third, the young population of official age for education is used to control for the size effect, namely that a larger proportion of pupils/students could mean a higher budget allocated to education. Finally, we have the fertility rate that is used as a proxy for the proportion of parents in the voting population. Parents are expected to push for more spending on public education as their children benefit directly from a higher quality of education services. ${ }^{17}$

The macroeconomic variables GDP per capita (GDPpc) and real GDP growth (RGDPgr) are used as control variables. The former variable is an indicator of the level of economic development in a country and the latter is used as a control for the business cycle. In addition, we include two fiscal variables, tax revenues (TaxRev), total social expenditure (TotSocExp) and social expenditure not including retirement spending (SocExp), in order to control for the size of the government and the generosity of the welfare state. Tax receipts include taxes on income, profits and capital gains and social security contributions. Respectively, social expenditure includes survivors and incapacityrelated benefits, health, family, active labor market programmes, unemployment, housing and other social policy areas.

The variable MYS (Mean Years of Schooling) illustrates the average number of years of education received by people aged 25 and older. This variable tries to capture the quality of the educational system as referred in Morales, Fortes, and Guarnido (2013). It is assumed that the more you study the better your educational level. In addition, we use three institutional variables, globalization index (GI), index of voice and accountability (VAI) and index of economic freedom (EFI). ${ }^{18}$ The first one shows how globalised a country is at the political, economic, cultural and social level. The underlying hypothesis is that the more open the economy is, the more countries are engaged in the "race to the bottom", reducing their spending and taxes in order to be more competitive vis-a-vis the rest of the world. The second index captures perceptions of the extent to which a country's citizens are able to participate in selecting their government, as well as freedom of expression, freedom of association, and a free media; in general, the variable captures the level of democracy in a country. It is expected that a higher level of democracy will lead to higher education spending. Finally, the last index includes assessments on commercial policy, government tax load, government intervention in the economy, monetary policy, foreign investment and capital flow, foreign activity, financial activity, salary and price control, property rights, and black market regulation and activity. Here too, it is expected that a higher degree of economic freedom leads to a larger amount spent on education policy.

Furthermore, we include in our model a dummy variable (Left) that accounts for the political ideology of the governing party. The dummy variable takes 1 when the government is either left-wing or social-democratic and 0 otherwise. It is predicted that left-wing governments are more fervent toward redistribution through social policies and education in order to favour their electoral base

\footnotetext{
${ }^{17}$ The fertility rate variable appears only in the per-student model specifications.

${ }^{18}$ All three indices are taken from Morales, Fortes, and Guarnido (2013).
} 
that lies among poorer social layers (Castles 1989; Busemeyer 2007). In addition, as it is shown empirically, left-wing governments favour more generous spending packages on social policies and therefore on education (Roubini and Sachs 1989).

Finally, we show in Table 1 the descriptive statistics of pre-primary (PPES), primary (PES), secondary (SES) and tertiary (TERES) education spending and the population of the official age (ppoap, poap, soap, toap) for these levels of education, respectively. These variables are used in order to investigate the effect of projected ageing per level of education (see Table 5).

\subsection{Methodology}

Our empirical approach complements the existing evidence on the determinants of public education spending at a cross-national level (Castles 1989; Busemeyer 2007; Morales, Fortes, and Guarnido 2013; Krieger and Ruhose 2013). These studies identify a set of variables that explains most of the variation in public education expenditure. Nevertheless, we extend the literature by focusing on the demographic transition and adding into the model variables that capture the current and future demographic features, such as current, projected old dependency ratio and fertility rate.

In order to choose our estimation strategy we conduct some diagnostic tests. Primarily, we have to decide between pooled OLS - which takes into account both between and within variation - and Random Effects (RE) which consider that the differences across countries have a significant influence on the dependent variable. In order to decide, we use the adjusted instead of the simple Breusch and Pagan (1980) Lagrange multiplier (LM) test. It might be the case that, in the presence of first-order serial correlation, the simple LM test by Breusch-Pagan 1980 too often rejects the correct null hypothesis of no random effects. Therefore, we have to conduct some complementary tests: the Baltagi and Li (1991) test for first-order serial correlation and the Baltagi and Li (1995) joint test for serial correlation and random effects. ${ }^{19}$ According to the outcome of these tests, the Ho hypothesis that the variance of the random effect is zero or that there are no individual effects in the model is rejected. Therefore, in the presence of country-specific characteristics (individual) heterogeneity, we have to decide between using random or fixed effects. Thus, we apply the test introduced by Hausman (1978), which leads us to a strong rejection of the null hypothesis that random effects provide consistent estimates or that there is no correlation between the error term and the independent variables. Therefore, the test indicates use of the fixed effects method that produces a consistent estimator. This method takes into account the within variation (over time) ${ }^{20}$ and controls for the unobserved characteristics that remain constant over the years and that might affect public expenditure on education, like culture heritage or religion, etc. ${ }^{21}$

Additionally, we conduct a series of other diagnostic tests: the modified Wald test for heteroscedasticity by Baum (2001); cross-sectional dependence tests by Frees (1995) and Pesaran (2004); and serial correlation test or the test for autocorrelation by ?). ${ }^{22}$ These tests first show that the

\footnotetext{
${ }^{19}$ These tests show that both serial correlation and random effects are present.

${ }^{20}$ The test for time fixed effects reveals that no time fixed effects are needed in our specification of the model.

${ }^{21}$ As referred in Castles (1994), cultural heritage and the tradition of Catholicism can play an important role in public expenditure on education. The countries that have Catholicism as their predominant religion might have to spend less on education of children as the Catholic Church undertakes a large part of the children's education.

${ }^{22}$ The latter is in addition to the previous Baltagi-Li test, as we saw above.
} 
idiosyncratic errors are heteroscedastic, meaning that the variation of the errors across countries is not constant. Second, there is contemporaneous correlation, namely the errors between countries are correlated, and third there is a first-order autocorrelation in errors within countries. As mentioned in Cameron and Trivedi (2010), ignoring cross-sectional dependence and correlation of errors over time can lead to systematic bias and thus to erroneous results.

Therefore, we have to use estimation methods that allow us to conduct consistent estimations in the presence of $\mathrm{AR}(1)$ autocorrelation within panels and cross-sectional correlation and heteroscedasticity across panels. For that purpose, we use an estimator (SCC) introduced by Hoechle (2007), that produces Driscoll and Kraay (1998) standard errors for the estimated coefficients using fixed effects. In our specification of this estimator, the error structure is assumed to be heteroscedastic, autocorrelated up to one lag and correlated between the countries. As mentioned in Hoechle (2007), Driscoll-Kraay standard errors are robust to very general forms of cross-sectional and temporal dependence when the time dimension is large enough. Additionally, their particular technique to estimate standard errors does not impose any restrictions on the number of countries, which can be even bigger than the number of periods. Finally, the implementation of Driscoll and Kraay's covariance estimator works for both balanced and unbalanced panels (Cameron and Trivedi 2010). All the above properties make this estimator suitable for our panel data.

$$
Y_{i, t}=b+\beta Z_{i, t}^{\prime}+\alpha_{i}+\epsilon_{i, t}
$$

where $\mathrm{i}=1 \ldots 31, \mathrm{t}=1996 \ldots 2015$, and $\Upsilon_{i, t}$ is education expenditure as a \% of GDP (or expenditure per student) of country $\mathrm{i}$ at time $\mathrm{t}$. All the explanatory variables are included in $\mathrm{Z}_{i, t}$. The demographic variables: old dependency ratio (ODR) or future old dependency ratio (PR.ODR), the young population of official age for education (PopEduc) and fertility rate. Macroeconomic control variables: GDP per capita (GDPpc) and real GDP growth rate (RGDPgr). Fiscal control variables: tax revenues (TaxRev) and total social expenditure (TotSocExp). ${ }^{23}$ Control for the quality of education: mean years of schooling (MYS). Institutional control variables (indices): globalization (GI), voice and accountability (VAI) and economic freedom index (E.F.I). Dummy variable for the political ideology of the government: Left. Finally, b is the constant term , $\beta$ is a coefficient vector, $\alpha_{i}$ represents the unobserved country-specific characteristics and $\epsilon_{i, t}$ is the idiosyncratic error term.

At this juncture, we should emphasize that, by using an aggregate data model of this kind, we are likely to be facing the usual problems of endogeneity. One potential problem might be the presence of reverse causality between education spending and the old-age dependency ratio. In this case, higher education spending could negatively influence the fertility rate and, in the long run, may essentially lead to a higher old-age dependency ratio. However, the impact of education on the fertility rate is far from straightforward. On the one hand, more educated women tend to have fewer children (Becker, Murphy, and Tamura 1990; Galor and Weil 1996) yet, on the other, as discussed in Esping-Andersen and Billari (2015), recent studies conducted in some OECD countries point to a reversal of this negative relationship between education and fertility. In addition, it could be argued that the more educated tend to live longer, increasing the old-age dependency ratio. However, it

\footnotetext{
${ }^{23}$ Later, in the regressions, we "break" the total social expenditure into two variables, total retirement spending (TPS) and the rest of social expenditure (SocExp).
} 
is plausible to assume that both of these effects (decreased fertility and prolonged life expectancy) take place in the long run - after one generation - rather than in the short period examined in this study. A further source of potential reverse causality could be endogenous migration. For example, generous spending on education could plausibly increase migration of the sort that would increase the future old-age dependency ratio. Again, this is more of a long-run effect and such a demographic change would take time to occur. Hence, the potential endogeneity problems of our analysis seem to be limited.

The general response to potential problems of endogeneity of this nature would be to reduce any causality claims that we might make, based on the nature of the data and the difficulty in using instrumental variable techniques to tackle the endogeneity problems properly. Ultimately, however, the main goal of the empirical analysis of aggregate data models is to identify connections of interest and to test theoretical predictions and hypotheses.

\section{The effect of current population ageing on education spend- ing: intergenerational conflict}

We begin our analysis with a replication of past studies. More specifically, we examine the direct impact of population ageing on public education expenditure. As discussed above, the increasing percentage of elderly in the population can be expected to have a negative effect on educational spending (intergenerational conflict). In order to test whether there is a conflict in relation to fiscal resources between the generation of people aged over 65 and the generation of young people, we employ the old-age dependency ratio (ODR).

As can be seen in the Table 2, the effect of the ODR on total education spending (size), without controlling for total social expenditure and for the institutional indices, is positive and statistically non-significant (reg. 1). However, when we take into account total social expenditure, the effect of the ODR on education spending becomes negative, as expected by the intergenerational conflict hypothesis (reg. 2 and 3). The reason for running the model sequentially and starting without including total social expenditure is the plausible strong relationship between education spending and total social expenditure. It is reasonable to expect people to vote for social packages as a whole (pensions and education). For instance, if voters are willing to support an extended welfare state, they might also be willing to support higher education spending. However, if we do not take into account social expenditure then, as our results show, the ODR can absorb these effects. A closer look shows that a $1 \%$ increase in the ODR generates a $0.041 \%$ reduction in total education expenditure (reg. 3). However, as is shown in regression 5 and 6 , the old dependency ratio has positive but not significant effect on education spending per student (generosity of the education system). 
Table 2: Current old dependency ratio and education expenditures

\begin{tabular}{|c|c|c|c|c|c|c|}
\hline \multicolumn{4}{|c|}{ Total Education Spending (\% of GDP) } & \multicolumn{3}{|c|}{ Education Spending per Student } \\
\hline & $(1)$ & $(2)$ & $(3)$ & $(4)$ & $(5)$ & $(6)$ \\
\hline \multirow[t]{2}{*}{ ODR } & 0.0044 & $-0.0448^{* *}$ & $-0.0411^{*}$ & $0.0597 \dagger$ & 0.0198 & 0.0366 \\
\hline & $(0.017)$ & $(0.014)$ & $(0.015)$ & $(0.029)$ & $(0.033)$ & $(0.034)$ \\
\hline \multirow[t]{2}{*}{ TotSocExp } & & $0.1325^{* * *}$ & $0.1361^{* * *}$ & & $0.1425^{*}$ & $0.1420^{*}$ \\
\hline & & $(0.022)$ & $(0.023)$ & & $(0.054)$ & $(0.057)$ \\
\hline \multirow[t]{2}{*}{ PopEduc } & $0.0324^{* *}$ & 0.0009 & -0.0018 & & & \\
\hline & $(0.011)$ & $(0.012)$ & $(0.015)$ & & & \\
\hline \multirow[t]{2}{*}{ GDPpc } & 0.0040 & 0.0042 & 0.0035 & $0.2379^{* * *}$ & $0.2343^{* * *}$ & $0.2353^{* * *}$ \\
\hline & $(0.008)$ & $(0.007)$ & $(0.006)$ & $(0.009)$ & $(0.007)$ & $(0.008)$ \\
\hline \multirow[t]{2}{*}{ RGDPgr } & $-0.0336^{* * *}$ & -0.0020 & -0.0042 & $-0.0514^{* * *}$ & -0.0147 & -0.0168 \\
\hline & $(0.005)$ & $(0.009)$ & $(0.009)$ & $(0.012)$ & $(0.027)$ & $(0.029)$ \\
\hline \multirow[t]{2}{*}{ TaxRev } & 0.0450 & 0.0239 & 0.0229 & 0.0326 & 0.0086 & 0.0072 \\
\hline & $(0.035)$ & $(0.023)$ & $(0.023)$ & $(0.040)$ & $(0.030)$ & $(0.029)$ \\
\hline \multirow[t]{2}{*}{ MYS } & 0.0645 & 0.0441 & 0.0302 & 0.1774 & 0.1810 & 0.1670 \\
\hline & $(0.050)$ & $(0.032)$ & $(0.043)$ & $(0.123)$ & $(0.120)$ & $(0.127)$ \\
\hline \multirow[t]{2}{*}{ Left } & 0.0591 & 0.0639 & 0.0425 & $0.1705^{*}$ & $0.1746^{*}$ & $0.1635^{*}$ \\
\hline & $(0.054)$ & $(0.053)$ & $(0.047)$ & $(0.071)$ & $(0.065)$ & $(0.063)$ \\
\hline \multirow[t]{2}{*}{ Fertility } & & & & 0.6388 & $0.8439^{*}$ & $0.8663^{*}$ \\
\hline & & & & $(0.417)$ & $(0.393)$ & $(0.353)$ \\
\hline \multirow[t]{2}{*}{ GI } & & & -0.0022 & & & -0.0172 \\
\hline & & & $(0.003)$ & & & $(0.012)$ \\
\hline \multirow[t]{2}{*}{ VAI } & & & $0.8677^{* * *}$ & & & $0.4191 \dagger$ \\
\hline & & & $(0.114)$ & & & $(0.218)$ \\
\hline \multirow[t]{2}{*}{ EFI } & & & 0.0076 & & & 0.0042 \\
\hline & & & $(0.008)$ & & & $(0.011)$ \\
\hline Obs. & 608 & 597 & 597 & 606 & 595 & 595 \\
\hline $\mathrm{R}^{2}$-within & 0.0955 & 0.2316 & 0.2625 & 0.9042 & 0.9124 & 0.9134 \\
\hline
\end{tabular}

Note: Fixed effects regressions with Driscoll-Kraay standard errors reported in parentheses, ${ }^{* *} p<0.001,{ }^{*} p<0.01,{ }^{*} p<0.05, \dagger p<0.10$. Education spending per student and GDPpc are measured in $\$ 1000$ and population of the official age for education (PopEduc) is measured in millions of people. ODR: Old dependency ratio. MYS: Mean years of schooling. Institutional variables: Globalization index (GI), Voice and Accountability Index (VAI) and Economic Free- dom Index (EFI). Constant term is included but not reported.

Regarding the performance of the control variables, it seems that the level of economic development (GDPpc) has a positive and significant impact only on per-student spending (reg. 4, 5 and 6). Moreover, as it is obvious, education spending is not affected significantly by the business cycle (real GDP growth). In addition, the level of fiscal resources (tax revenue) has the expected positive sign for total spending on education but they only weakly affect the level of education spending per student. Next, the size of the welfare state represented by total social expenditure has an important positive impact on both measures of education spending. ${ }^{24}$ The variable used as an approximation of education quality, the mean years of schooling (MYS), has no significant influence on education. Left-wing governments have important positive influence only on education spending per student. Finally, the fertility rate, which reflects the interest of young parents in education spending, has a strongly positive influence on per-student spending. A higher fertility rate means more children

\footnotetext{
${ }^{24}$ The social expenditure used for these regressions also includes retirement spending.
} 
per couple and that makes young parents more willing to "push" for a higher level of educational expenditure. We could call that the "political power of parents" hypothesis.

In regard to the institutional variables in Table 2, globalization index (GI), Voice and Accountability Index (VAI) and Economic Freedom Index (EFI) have the expected signs. The first one has a negative sign, reflecting the "race to the bottom" hypothesis that claims that more globalised countries engage more actively in competition with other countries and, hence, aim to lower the level of public spending in order to be able to lower taxes and become more competitive. The second index has a positive effect on both measures of education spending, showing that a higher level of democracy promotes the expansion of the public education system. The Index of Economic Freedom shows that the process of economic liberalization has encouraged higher spending on public education.

In this section, we test the intergenerational conflict hypothesis using data for OECD countries. In line with previous studies Krieger and Ruhose (2013), we find only partial support for the intergenerational conflict, since the ODR has a significant and negative effect only on total education spending rather than on education spending per student. This result suggests that the relationship between population ageing and education spending might be more complicated than was first thought and that we should examine it more closely. This is precisely what we do in the next section.

\section{Intergenerational conflict revisited: the role of the link between pensions and education}

Most previous studies of the intergenerational conflict focus on the direct effect of the elderly population on education spending and fail to take into account the presence of many plausible indirect effects. As discussed in the introduction, an increase in the ODR can have two opposite effects on education expenditure. On the one hand, we find the well-known negative effect due to the increased numbers of the elderly putting greater pressure on fiscal resources (direct effect). On the other hand, there might be a positive effect derived from the link between pensions and education. The working-age generation, in the face of population ageing, realizes that the increasing number of elderly will make the PAYG pension system less profitable in terms of pensions per retiree and financially unsustainable. Hence, the middle-aged generation decides to back investment in the education of young people in order to boost their productivity and, consequently, the level of their contributions to social security and the revenues from taxing their future income (indirect effect). ${ }^{25}$

One way to investigate further the relationship between current population ageing and education spending - allowing for indirect effects - is to take into account the pensions spending and to check for possible non-linear impacts. One can claim that it is plausible to assume that the impact of population ageing on education expenditure depends on the scarcity of fiscal resources. ${ }^{26}$ For instance, the effect of the old dependency ratio on education spending might depend on the level of total retirement expenditure. Thus, we need to disentangle the effect of retirement spending

\footnotetext{
${ }^{25}$ However, note here that the latter effect is likely to be limited as the current ODR is more of a concern to the elderly than it is to the middle-aged generation (see Figure 2).

${ }^{26}$ It is shown in the Appendix A Tables 6 and 7, that the effect of population ageing on pensions expenditure depends on the scarcity of fiscal resources and after a certain point reduces the amount spent per retiree.
} 
from the effect of total social expenditure on educational outlays. In order to do so, we "break" total social expenditure into two parts, social expenditure (survivors and incapacity-related benefits, health, family, active labor market programmes, unemployment, housing and other social policy areas) and total pensions spending (TPS). In this way, we are able to interact TPS with the old dependency ratio in order to capture potential non-linearities in the relationship of population ageing and education expenditure. In addition, we obtain the individual effect of retirement spending on education expenditure in order to test whether there is a direct link between these two public policies. $^{27}$

As we can see from the regression 1 (3) of the Table 3, total pensions spending has a positive but non-significant (strongly significant) effect on total education spending (education spending per student), and the new variable for social expenditure is strongly significant and positive. Moreover, we do not observe any significant evidence in favour of the intergenerational conflict. The negative effect from Table 2 is absorbed by TPS, probably due to the presence of the indirect effect of current old dependency ratio on education spending. Moreover, in the regression 2 (4), where the interaction term between the old dependency ratio and retirement spending is taken into account, we can observe that the individual effect of both variables (ODR and TPS) becomes significantly positive and, additionally, the interaction term is negative on a high level of statistical significance. In technical terms, this means that the effect of the old dependency ratio on total education outlays is non-linear and depends on the level of total retirement expenditure. ${ }^{28}$ More specifically, the effect of the old dependency ratio on education is positive until a certain level of total retirement spending (TPS $=8 \%$ ). When the level of retirement expenditure exceeds $8 \%$ of GDP, then the effect of the old dependency ratio on total education outlays becomes negative. ${ }^{29}$

As it is mentioned above, an increase in the old dependency ratio can have two opposite effects on education spending. There is the negative effect of the intergenerational conflict due to the increasing number of elderly and the positive effect derived from the link between pensions and education. Therefore, when retirement spending is low, the former effect is dominated by the latter and hence the net effect on education expenditure is positive. This effect is a result of the choice by the working-age generation to invest public resources in education in order to ensure their future pensions. However, when the total expenditure on retirement is quite high, the former effect

\footnotetext{
${ }^{27}$ As suggested by Kemnitz (2000), in contrast with the negative predictions for the social security system due to higher life expectancy and lower fertility, the demographic transition has beneficial effects on both education and pensions. According to his theoretical model, in a steady state equilibrium there is higher investment in per capita human capital and a higher contribution rate to the social security

${ }^{28}$ Isolating the effect of the ODR and TPS on total education spending, we obtain the expression below:
}

$$
T E S=0.1011 * O D R+0.3628 * T P S-0.0142 * O D R * T P S
$$

In order to obtain the effect of the old dependency ratio on total education spending, we take the derivative of TES with respect to the ODR:

$$
\partial T E S / \partial O D R=0.1011-0.0142 * T P S
$$

In the same way, we can obtain the derivatives with respect to TPS.

${ }^{29}$ Similarly, after a certain point $(\mathrm{ODR}=26 \%)$, the effect of increasing spending on retirement has a negative effect on total education spending. The theoretical intuition behind this result can be derived from the intergenerational conflict hypothesis. Thus, when the old cohort is politically stronger (higher ODR), an increase in total retirement spending is financed out of the same public resources that are used for education expenditure, bringing about a negative impact on education expenditure. 
dominates the latter, and hence the net effect on education is negative. This outcome reflects the fact that, when there are limited fiscal resources, an increase in the political power of the elderly is translated into a decrease in education expenditure. This can be attributed to the old generation attempting to appropriate more public resources in its own favour.

Table 3: Population ageing interacted with pension spending

\begin{tabular}{|c|c|c|c|c|c|c|}
\hline \multicolumn{3}{|c|}{ Total Education Spending (\% of GDP) } & \multicolumn{3}{|c|}{ Education Spending per Student } & \multirow[b]{2}{*}{$(6)$} \\
\hline & $(1)$ & $(2)$ & $(3)$ & $(4)$ & $(5)$ & \\
\hline \multirow{2}{*}{ ODR } & -0.0192 & $0.1011^{* * *}$ & 0.0309 & $0.0961^{*}$ & $0.0474^{*}$ & -0.0214 \\
\hline & $(0.016)$ & $(0.017)$ & $(0.027)$ & $(0.045)$ & $(0.022)$ & $(0.033)$ \\
\hline \multirow[t]{2}{*}{ TPS } & 0.0077 & $0.3628^{* * *}$ & $0.0861^{* *}$ & $0.2872^{* * *}$ & & \\
\hline & $(0.040)$ & $(0.064)$ & $(0.028)$ & $(0.069)$ & & \\
\hline \multirow[t]{2}{*}{ TPS*ODR } & & $-0.0142^{* * *}$ & & $-0.0078^{*}$ & & \\
\hline & & $(0.002)$ & & $(0.003)$ & & \\
\hline \multirow[t]{2}{*}{ PSPR } & & & & & $0.0591^{* * *}$ & -0.0460 \\
\hline & & & & & $(0.014)$ & $(0.030)$ \\
\hline \multirow[t]{2}{*}{ PSPR*ODR } & & & & & & $0.0041^{* *}$ \\
\hline & & & & & & $(0.001)$ \\
\hline \multirow[t]{2}{*}{ SocExp } & $0.2137^{* * *}$ & $0.1995^{* * *}$ & $0.2367^{* * *}$ & $0.2280^{* * *}$ & $0.2419^{* * *}$ & $0.2556^{* * *}$ \\
\hline & $(0.013)$ & $(0.011)$ & $(0.039)$ & $(0.042)$ & $(0.038)$ & $(0.038)$ \\
\hline \multirow[t]{2}{*}{ PopEduc } & 0.0025 & -0.0076 & & & & \\
\hline & $(0.014)$ & $(0.021)$ & & & & \\
\hline \multirow[t]{2}{*}{ GDPpc } & 0.0000 & -0.0043 & $0.2343^{* * *}$ & $0.2299 * * *$ & $0.2114^{* * *}$ & $0.2204^{* * *}$ \\
\hline & $(0.005)$ & $(0.006)$ & $(0.007)$ & $(0.006)$ & $(0.011)$ & $(0.011)$ \\
\hline \multirow[t]{2}{*}{ RGDPgr } & 0.0036 & 0.0008 & 0.0083 & 0.0081 & 0.0096 & 0.0091 \\
\hline & $(0.006)$ & $(0.005)$ & $(0.011)$ & $(0.011)$ & $(0.010)$ & $(0.010)$ \\
\hline \multirow[t]{2}{*}{ TaxRev } & 0.0213 & 0.0223 & -0.0076 & -0.0040 & -0.0026 & -0.0075 \\
\hline & $(0.015)$ & $(0.013)$ & $(0.019)$ & $(0.018)$ & $(0.019)$ & $(0.019)$ \\
\hline \multirow[t]{2}{*}{ MYS } & 0.0341 & 0.0752 & 0.0718 & 0.1033 & 0.0603 & 0.0052 \\
\hline & $(0.052)$ & $(0.062)$ & $(0.120)$ & $(0.131)$ & $(0.126)$ & $(0.133)$ \\
\hline \multirow[t]{2}{*}{ Left } & 0.0678 & 0.0863 & $0.1549^{*}$ & $0.1661^{*}$ & $0.1436 \dagger$ & 0.1153 \\
\hline & $(0.047)$ & $(0.053)$ & $(0.071)$ & $(0.076)$ & $(0.070)$ & $(0.068)$ \\
\hline \multirow[t]{2}{*}{ Fertility } & & & $0.8428^{*}$ & $1.0891^{* *}$ & $0.7406^{*}$ & 0.4763 \\
\hline & & & $(0.303)$ & $(0.353)$ & $(0.288)$ & $(0.302)$ \\
\hline Instit.Variab. & Yes & Yes & Yes & Yes & Yes & Yes \\
\hline Obs. & 550 & 550 & 548 & 548 & 548 & 548 \\
\hline $\mathrm{R}^{2}$-within & 0.3392 & 0.3782 & 0.9210 & 0.9217 & 0.9221 & 0.9228 \\
\hline
\end{tabular}

Note: Fixed effects regressions with Driscoll-Kraay standard errors reported in parentheses, ${ }^{* * *} p<0.001,{ }^{* *} p<0.01,{ }^{*} p<0.05, \dagger p<0.10$. Education spending per student, pensions spending per retiree (PSPR) and GDPpc are measured in $\$ 1000$ and population of the official age for education (PopEduc) is measured in millions of people. ODR: Old dependency ratio. TPS: Total pension spending. MYS: Mean years of schooling. Institutional variables: Globalization index (GI), Voice and Accountability Index (VAI) and Economic Freedom Index (EFI). SocExp represents social expenditures excluding pension spending. Constant term is included but not reported.

Furthermore, as is evident from Table 3 (reg. 4), the same interaction effect is present in the case of education spending per student. The effect of old dependency ratio depends on the level of the total retirement spending. However, the effect of the old dependency ratio becomes negative 
only after the level of total retirement spending is above $13 \%$ of GDP. ${ }^{30}$ Therefore, the negative impact of the interaction terms takes place only at a very high level of the old dependency ratio and retirement spending, respectively. This evidence is in favour of the intergenerational conflict hypothesis that claims that there is competition for fiscal resources between young and old cohorts. However, we show that the effect of intergenerational conflict is non-linear rather than linear, as it is highlighted in the existent literature.

Last but not least, in regressions 5 and 6 we present the effect of retirement spending per retiree on education and the interaction of retirement spending with the old dependency ratio, respectively. It is obvious that there is no interaction between the old dependency ratio and average spending per retiree (reg. 6). Hence, the impact of retirement spending per retiree and the impact of the old dependency ratio on education do not depend on each other. As we can see from Table 3, it seems that the higher the average spending on retirees, the higher the education expenditure per student. The intuition behind this result is that an increase in education spending per student as a result of an increase in average pensions is financially backed by the working-age generation because, for them, this is a way to secure their future pensions. Moreover, this could be an indication that pensions and education are also directly and positively linked. More specifically, an average increase of $\$ 1000$ in pensions results in an increase of $\$ 59$ in education spending per student. For the same reason a one percentage point increase in the old dependency ratio enhances education spending with $\$ 47$ per student.

Following our focus on the current ODR, we find that there is competition for resources, at least above a certain level of total retirement spending. This outcome probably reflects the fact that population ageing has a different impact on working-age and elderly voters. Moreover, it is plausible to claim that current population ageing is more closely related to intergenerational conflict (direct effect) than it is to the positive link between pensions and education (indirect effect). The latter is quite intuitively associated with the future rather than with current population ageing. The working-age voters worry more about the future than they do about current population ageing for the simple reason that they receive their pensions in the future. Hence, it is interesting to consider also the effect of the future ODR on education spending as the positive indirect effect can be expected to be reinforced. This is what we do in the next section.

\section{The impact of the projected population ageing on educa- tion spending}

In this section, we move away from the focus taken by the existing empirical literature and indeed that adopted in the previous sections herein. Instead of employing the current ODR, we employ the projected ODR (PRODR) to examine the effect of future population ageing on education. The latter corresponds to the period (2018-2035) ${ }^{31}$, allowing us to capture the retirement of the generation of "baby boomers" and, hence, the massive increase in the elderly population (see, Figure 1).

\footnotetext{
${ }^{30}$ Likewise, in this case the effect of total retirement spending on education becomes negative at the point where the level of the ODR is $37 \%$.

${ }^{31}$ From 2015 to 2017 we use the real ODR rather than the projected one.
} 
Future population ageing in contrast to current population ageing is expected to reinforce the indirect (positive) effect and mitigate the direct (negative) impact. Following the same mechanism as in the previous section, the former captures the reaction of the middle aged to investments in current public education - as a response to the decreasing future financability of the pension system - and the latter reflects the fiscal pressure driven by the increasing number of elderly. However, in this case, future population ageing has a stronger indirect effect because the working-age voters are more concerned with the future than they are about current population ageing, for the simple reason that they care more about the generosity of future pensions than they do about that of current pensions. Moreover, the direct effect is expected to be limited because there is no fiscal struggle between generations as the increasing number of future retirees does not concern the current elderly. Overall, the effect of future ageing is predicted to be positive (see, Figure 2).

Figure 2: Generation effect on education spending

\begin{tabular}{|c|c|c|c|}
\hline & Middle aged (indirect effect) & Elderly (direct effect) & Overall \\
\hline ODR & moderate positive & strong negative & moderate negative \\
\hline PRODR & strong positive & weak negative & strong positive \\
\hline
\end{tabular}

As is evident from Table 4, the PRODR has the expected positive impact on both total level of education spending and spending per student. In both cases, we control either for the size (TPS) or the generosity (PSPR) of the pension system (reg. $1 \& 3$ and $2 \& 4$, respectively). In this way, we control for the fiscal pressure attributable to the increased number of retirees. Hence, in a way, we also account for the number of current retirees - reflected in the TPS and PSPR - which is expected to have a negative influence on education spending. However, as can be seen, the size and generosity of pensions have overall positive and significant impacts on education generosity (reg. 3 and 4). This can be attributed to the positively reinforced indirect effect - operating via the link between pensions and the education system - over the direct effect on education.

A closer look reveals that a one percentage point rise in the proportion of old people in the future, ceteris paribus, generates an increase of about $0.0207 \%$ (reg. 1 and 2) in total education spending and around a \$47-60 rise in expenditure per student (reg. 3 and 4). These results are in contrast with the negative impact that the current ODR has on education spending in Tables 2 and 3. It might be argued that these differences are attributable to the limited negative impact of intergenerational conflict. Future population ageing is not a concern for the current old generation and, hence, they do not "fight" for public resources now. In contrast, the incentives for the middle aged to invest in education so as to preserve future pensions are reinforced. As a result, the net effect of the projected future ageing is positive.

Another interesting aspect that is observed in 4 is the significantly positive effect of the fertility rate on the education expenditure (reg. 3 and 4). More specifically, one percentage point increase in the fertility rate brings about roughly a $\$ 885-970$ increase in the generosity of the education system (reg. 3 and 4). This outcome can be associated with the parental willingness to support public education. In general, most of the control variables in these specifications of the model behave as expected by the literature. The political ideology seems to have only a weak role in the determination 
of education expenses. More specifically, left-wing and social-democratic governments tend to spend more per student than their ideological opponents. As in the previous section, the level of the welfare state (excluding pensions) and economic development have a positive and very significant impact on per-student spending. Finally, institutional indices have significant effects in the expected direction.

Table 4: Future ageing and education expenditure

\begin{tabular}{|c|c|c|c|c|}
\hline \multicolumn{2}{|c|}{ Total Education Spending } & \multicolumn{3}{|c|}{ Education Spending per Student } \\
\hline & $(1)$ & $(2)$ & $(3)$ & $(4)$ \\
\hline \multirow[t]{2}{*}{ PRODR } & $0.0207^{*}$ & $0.0206^{*}$ & $0.0473^{* *}$ & $0.0605^{* * *}$ \\
\hline & $(0.008)$ & $(0.008)$ & $(0.014)$ & $(0.015)$ \\
\hline \multirow[t]{2}{*}{ TPS } & -0.0125 & & $0.1029 * * *$ & \\
\hline & $(0.037)$ & & $(0.018)$ & \\
\hline \multirow{2}{*}{ PSPR } & & 0.0035 & & $0.0717^{* * *}$ \\
\hline & & $(0.014)$ & & $(0.014)$ \\
\hline \multirow[t]{2}{*}{ SocExp } & $0.2012^{* * *}$ & $0.1993^{* * *}$ & $0.2136^{* * *}$ & $0.2159^{* * *}$ \\
\hline & $(0.014)$ & $(0.012)$ & $(0.039)$ & $(0.035)$ \\
\hline \multirow[t]{2}{*}{ PopEduc } & 0.0103 & 0.0115 & & \\
\hline & $(0.010)$ & $(0.008)$ & & \\
\hline \multirow[t]{2}{*}{ GDPpc } & -0.0074 & -0.0086 & $0.2192^{* * *}$ & $0.1873^{* * *}$ \\
\hline & $(0.006)$ & $(0.010)$ & $(0.008)$ & $(0.013)$ \\
\hline \multirow[t]{2}{*}{ RGDPgr } & 0.0025 & 0.0037 & 0.0096 & 0.0113 \\
\hline & $(0.006)$ & $(0.007)$ & $(0.009)$ & $(0.008)$ \\
\hline \multirow[t]{2}{*}{ TaxRev } & 0.0195 & 0.0200 & -0.0038 & 0.0047 \\
\hline & $(0.016)$ & $(0.017)$ & $(0.021)$ & $(0.022)$ \\
\hline \multirow[t]{2}{*}{ MYS } & -0.0173 & -0.0226 & 0.0362 & 0.0296 \\
\hline & $(0.051)$ & $(0.049)$ & $(0.129)$ & $(0.136)$ \\
\hline \multirow[t]{2}{*}{ Left } & 0.0672 & 0.0631 & $0.1472 \dagger$ & $0.1323 \dagger$ \\
\hline & $(0.048)$ & $(0.048)$ & $(0.071)$ & $(0.072)$ \\
\hline \multirow[t]{2}{*}{ Fertility } & & & $0.9701^{* *}$ & $0.8832^{*}$ \\
\hline & & & $(0.324)$ & $(0.318)$ \\
\hline Instit.Variab. & Yes & Yes & Yes & Yes \\
\hline Obs. & 550 & 550 & 548 & 548 \\
\hline $\mathrm{R}^{2}$-within & 0.3418 & 0.3416 & 0.9221 & 0.9235 \\
\hline
\end{tabular}

Note: Fixed effects regressions with Driscoll-Kraay standard errors reported in parentheses, ${ }^{* * *} p<0.001,{ }^{* *} p<0.01,{ }^{*} p<0.05, \dagger p<0.10 . \quad E d-$ ucation spending per student, pension spending per retiree (PSPR) and GDPpc are measured in $\$ 1000$ and population of the official age for education (PopEduc) is measured in millions of people. PRODR: Projected old dependency ratio. TPS: Total pension spending. MYS: Mean years of schooling. Institutional variables: Globalization index (GI), Voice and Accountability Index (VAI) and Economic Freedom Index (EFI). SocExp represents social expenditures excluding pension spending. Constant term is included but not reported.

The above findings are consistent with the main theoretical predictions of Kemnitz (2000) and Gradstein and Kaganovich (2004). More specifically, in order to interpret the results, it can be argued that the working-age generation, foreseeing the severe consequences of the ageing process for their retirement benefits, decide to exploit the current set-up of the PAYG pension system. Thus, they react to an increasing PRODR by investing in the education of young people "today" in order to boost their labor productivity and, consequently, the revenues from income tax "tomorrow". 
Hence, in this way, the fiscal resources generated from the investment of the working-age cohort in education now can be used to pay for their pensions in the future. Therefore, future population ageing - operating through the link mechanism between pensions and education - positively affects current education expenditure.

\section{The effect of the projected population ageing on disaggre- gated levels of public education}

In this section we go one step further by investigating which educational levels are the driving forces behind the impact of future population ageing on total education expenditure. Moreover, we examine to what extent they are affected by demographic transition that acts through the link mechanism between pensions and education. We investigate the effect of population ageing on public education per level (pre-primary, primary, secondary and tertiary). In order to estimate the effect of the projected population ageing, we employ the same model as in Table 4. In this specification of the model, among other variables we control for the total size of the pensions, social expenditure (excluding pensions) and the proportion of pupils/students per level of education. The dependent variables are spending by education level measured as a percentage of GDP.

As the Table 5 shows, spending on non-mandatory, pre-primary and tertiary education is positively affected by the increasing percentage of the elderly. In contrast, the impact on the mandatory, primary and secondary educational level is negative and positive but insignificant, respectively. One can argue that an increase in the projected old dependency ratio raises the future welfare state fiscal requirements (pensions and other social expenditure) as the number of beneficiaries increases. Hence, enhancing the productivity of the current and future generations as an attempt to generate additional fiscal resources (tax revenues) can be considered as the main reaction of the working-age population to handle the forthcoming financial sustainability issues of the welfare state. Thus, in order to

boost current and future productivity, voters decide to support investments in the non-mandatory levels of education and those more related to productivity, pre-primary and tertiary education. In our opinion, the investment in non-mandatory education takes place only because there is a space for political intervention. In other words, increasing the quality of the non-compulsory educational levels may have a larger positive effect on the participation rate of these educational levels than on participation in mandatory education.

More specifically, investment in pre-primary public education can positively affect the productivity of young parents (especially young mothers) by supporting them with such a time-consuming process as child-raising. Therefore, improving the quality of pre-primary education could eventually lead to an increase in productivity. However, in the case of primary and secondary education, the mandatory character of participation prevents such an investment from being beneficial for the productivity of current workers. Regarding the productivity of future workers, there is a positive impact from the projected population ageing on higher education spending. Consequently, one can expect that this could bring about an increase in participation in tertiary education and eventually lead to a future working generation with enhanced skills and productivity. In other words, as mentioned above, working-age voters, on considering their future public benefits, choose to support 
investments in higher education in order to boost the productivity of the young generation and "reap" the benefits from increased income tax in the future.

Table 5: Future ageing and education spending by level of education

\begin{tabular}{|c|c|c|c|c|}
\hline & PPES & PES & SES & TERES \\
\hline & (1) & $(2)$ & (3) & (4) \\
\hline \multirow[t]{2}{*}{ PRODR } & $0.0111^{* *}$ & -0.0084 & 0.0041 & $0.0151^{* * *}$ \\
\hline & $(0.004)$ & $(0.006)$ & $(0.008)$ & $(0.003)$ \\
\hline \multirow[t]{2}{*}{ TPS } & 0.0050 & 0.0140 & 0.0151 & -0.0073 \\
\hline & $(0.004)$ & $(0.009)$ & $(0.015)$ & $(0.011)$ \\
\hline \multirow[t]{2}{*}{ SocExp } & 0.0050 & $0.0710^{* * *}$ & $0.0626^{* * *}$ & $0.0383^{* * *}$ \\
\hline & $(0.007)$ & $(0.010)$ & $(0.014)$ & $(0.004)$ \\
\hline \multirow{2}{*}{ ppoap } & 0.0599 & & & \\
\hline & $(0.057)$ & & & \\
\hline \multirow[t]{2}{*}{ poap } & & 0.0007 & & \\
\hline & & $(0.051)$ & & \\
\hline \multirow[t]{2}{*}{ soap } & & & $0.1019^{* * *}$ & \\
\hline & & & $(0.016)$ & \\
\hline \multirow[t]{2}{*}{ toap } & & & & -0.0072 \\
\hline & & & & $(0.012)$ \\
\hline \multirow[t]{2}{*}{ GDPpc } & -0.0030 & -0.0024 & $-0.0127^{* *}$ & -0.0038 \\
\hline & $(0.004)$ & $(0.002)$ & $(0.004)$ & $(0.002)$ \\
\hline \multirow[t]{2}{*}{ RGDPgr } & -0.0042 & -0.0021 & -0.0001 & 0.0012 \\
\hline & $(0.003)$ & $(0.004)$ & $(0.003)$ & $(0.002)$ \\
\hline \multirow[t]{2}{*}{ TaxRev } & -0.0083 & -0.0097 & $0.0096 \dagger$ & -0.0003 \\
\hline & $(0.006)$ & $(0.006)$ & $(0.005)$ & $(0.002)$ \\
\hline \multirow[t]{2}{*}{ MYS } & 0.0268 & -0.0116 & 0.0105 & 0.0176 \\
\hline & $(0.025)$ & $(0.014)$ & $(0.017)$ & $(0.012)$ \\
\hline \multirow[t]{2}{*}{ Left } & $0.0211^{*}$ & $-0.0343^{*}$ & -0.0216 & 0.0018 \\
\hline & $(0.007)$ & $(0.012)$ & $(0.029)$ & $(0.008)$ \\
\hline Instit.Variab. & Yes & Yes & Yes & Yes \\
\hline Obs. & 421 & 418 & 425 & 445 \\
\hline $\mathrm{R}^{2}$-within & 0.2087 & 0.3571 & 0.2464 & 0.3420 \\
\hline
\end{tabular}

Note: Fixed effects regressions with Driscoll-Kraay standard errors reported in parentheses, ${ }^{* * *} p<0.001,{ }^{* *} p<0.01,{ }^{*} p<0.05$, $\dagger p<0.10$. PPES (ppoap), PES (poap), SES (soap) and TERES (toap) represent pre-primary, primary, secondary and tertiary, education spending (children population in millions), respectively. GDPpc is measured in \$1000. PRODR: Projected old dependency ratio. MYS: Mean years of schooling. Institutional variables: Globalization index (GI), Voice and Accountability Index (VAI) and Economic Freedom Index (EFI). Constant term is included but not reported.

\section{Conclusions}

The share of the elderly in the population of many developed countries is rising as the demographic transition runs its course. The implications of this trend for major public policies, including pensions and education, have been a chief concern for economists, as has its impact on the allocation of public funds among the different generations. Children and the elderly, located at opposite ends of the 
spectrum of dependency, are, as such, the chief beneficiaries of social spending. For this reason, a conflict of interests is likely to arise between the generations.

Here, we have reviewed the intergenerational conflict hypothesis, according to which increased numbers of the elderly seem set to result in more pensions and less expenditure on education (direct effect). As shown, this intergenerational conflict effect is present, but it is dependent on the overall level of pension spending. Thus, when this spending level is low and more public resources are available, an increase in the old dependency ratio has a positive (indirect) effect on education spending due to the positive link between pensions and education. However, when total retirement spending is high, an increase in the old dependency ratio has a negative impact on education spending, reflecting the struggle between generations for limited amounts of public resources. Hence, an increase in current levels of population ageing, which translates into an increase in the political power of the elderly (who obviously support more generous pension policies) seems to have a negative impact on both total spending on education and on spending per student.

The main focus of this paper has been on a future demographic change that seems set to strengthen the mechanism that links public pension and education policies. More specifically, we have tested the theoretical hypothesis - emerging from the studies of Kemnitz (2000) and Gradstein and Kaganovich (2004) - that population ageing results in a higher forward (education) reallocation of public funds. Our results show that, indeed, the projected (future) old dependency ratio has a positive impact on education expenditure and operates via the link between education and pensions (indirect effect). The specific design of the PAYG pension system creates the incentives to invest in education. The intuition underpinning the link is that the working-age generation, aware of the rise in life expectancy and the increasing number of retirees, invests more in public education "today" in order to derive some benefits in the form of higher contributions (income tax) for pensions "tomorrow". Therefore, even in the absence of altruism, middle-aged voters are in favor of a public education program as a way to improve their pensions, thanks to the increase in the productivity of future workers. This could have a number of policy implications in the context of the imminent demographic crisis faced by PAYG-financed pension systems. Educational expenditure can be seen as a complement or as an alternative pre-funding device to the long-discussed transition to a capitalization system.

Moreover, by disaggregating education expenditure by level of education, we have sought to determine whether future population ageing has a different impact according to each educational level. The results point solely to a positive effect on non-mandatory (pre-primary and tertiary) education spending. Our interpretation of this outcome is that investment in non-compulsory education only occurs because there is room for political intervention to increase participation in education and, consequently, the productivity of both current and future working-age generations.

The key lesson to be drawn from this study is that population ageing affects the working-age and the elderly generations in a different way. While current population ageing increases the number of retirees opposed to spending on education, the current and, especially, the future projection of population ageing stimulates (via the positive link between education and pensions) the working-age generation to support an expansionary education policy.

Further theoretical and empirical studies are clearly necessary. On the theoretical side, the reasons accounting for private transfers and their interaction with public transfers (as introduced 
by welfare state programs) need further investigation. On the empirical side, and related to these theoretical lines of investigation, the strong positive effect of fertility on education spending per student (which we report herein) could be analyzed as an indication of the political power of parents driven by altruism or other types of motivation. 


\section{Appendix}

\section{A Population Ageing and Pensions}

As we investigate the impact of the current and future population ageing on education expenditure it is also very interesting to examine how pensions - that are quite relative in our analysis to education - are affected by the demographic change. The main reason is to observe the dynamic in the relationship between our two main independent variables.

According to the literature on the political economy of social security, the ageing process affects the social security system through two opposing channels. ${ }^{32}$ On the one hand, there is the "fiscal leakage" hypothesis, which suggests that the increased proportion of elderly people decreases the expected profitability of pay-as-you-go pension systems for current working-age voters, thereby inducing them to favour lower current pensions. Therefore, the working-age generation repudiates the social security system (Breyer and Stolte 2001; Razin, Sadka, and Swagel 2002; Razin and Sadka 2007). On the other hand, population ageing makes the median voter older and hence more inclined to support higher expenses on pensions, the well-known in the literature "political power of elderly" hypothesis (Browning 1975; Boadway and Wildasin 1989; Breyer and Craig 1997; Mulligan and Sala-i Martin 1999; Tabellini 2000; Persson and Tabellini 2000; Disney 2007; Shelton 2008; Tepe and Vanhuysee 2009; Hollanders and Koster 2012). Nevertheless, Castles (2004) argues that the higher total spending on pensions is attributed to the design and some specific characteristics of the social security system rather than to population ageing. However, Castles admits that the cuts in pensions are negatively correlated with an increased political clout of the elderly. Alternatively, Lindert (1996) argues that the effect of the old dependency ratio on both the size and the generosity of the system is non-linear. When the old dependency ratio is low, the relationship with pension spending is positive but, as the ratio increases over the years, after a certain point the sign of the relationship becomes negative. As we show below we find similar results while replicating previous analysis of the impact of population change on pension's expenditure.

Our investigation is focused on the determinants of the size (as a percentage of GDP) and generosity (expenditures per pensioner) of the public pension system and how they are affected by demographic transition. We conduct a panel data analysis for 23 OECD countries over the period 1980-2010. ${ }^{33}$ We use intervals of five years for the period instead of 1 year in order to capture the political cycle in which pension reforms and changes in demographic structure usually take place. Using fixed effects, we deal with the large source of omitted variable bias by controlling the crosscountry unobserved heterogeneity. Our baseline model is constructed as a synthesis of the previous studies (Tepe and Vanhuysee 2009; Hollanders and Koster 2012).

$$
Y_{i, t}=c+\gamma X_{i, t}^{\prime}+\alpha_{i}+\mu_{t}+\epsilon_{i, t}
$$

\footnotetext{
32 Breyer (1994) and Galasso and Profeta (2002) provide good reviews of this literature.

${ }^{33}$ Australia, Austria, Belgium, Canada, Denmark, Finland, France, Germany, Greece, Iceland, Ireland, Italy, Japan, Luxembourg, Netherlands, New Zealand, Norway, Portugal, Spain, Sweden, Switzerland, U.K., U.S.
} 
where $\mathrm{i}=1 \ldots 23, \mathrm{t}=1, \ldots 6$. The dependent variable $\mathrm{Y}$ is the total pension spending as $\%$ of GDP (TPS) or pension spending per retiree (PSPR). ${ }^{34}$ First, our main focus is on the demographic variables: current old dependency ratio (ODR) or projected old dependency ratio (PRODR) or the ratio of the population above 55 years old over the working-age population (ODR+55). We chose these demographic variables in order to test the "elderly power" and the "fiscal leakage" hypotheses. Second, we include as control variables four macroeconomic indicators: GDP per capita (GDPpc), real GDP growth (RGDPgr), interest rate (Intrate) and trade openness (Openc). Third, we add two variables related to the labor market: unemployment (Unemp) and union density (Un.Den.). Fourth, we include political variables: type of government (G.T.) and government party (G.P.). ${ }^{35}$ In addition, in order to fit a two-way FE model, we include time fixed effects, $\mu_{t}$. In this way, we control for time effects in order to capture any unexpected variation or special events that may affect the dependent variable. Finally, $\mathrm{c}$ is the constant term , $\gamma$ is the coefficient vector, $\alpha_{i}$ represents the unobserved country-specific characteristics and $\epsilon_{i, t}$ is the idiosyncratic error term.

From Table 6 we can see that the total pension expenditure is affected positively by all the demographic variables except of projected old dependency ratio. This result can be attributed to the size effect; the higher number of old people means more total expenditure. However, the effect of the same demographic variables on the pension spending per retiree is negative and significant only for the current and projected in the future old dependency ratio. These outcomes are in favour of the "fiscal leakage" hypothesis. The high current and projected in the future old dependency ratio make the pay-as-you-go system less profitable for the currently working voters who push for less generous pensions. It is interesting to notice here that, when we include part of the working-age voters in our demographic variable $(\mathrm{ODR}+55)$, the negative effect is moderated (reg. 4). This can be attributed to the fact that the working-age voters close to retirement age will not claim less generous pensions, even though the profitability of the system is lower because they are about to retire.

Extending the scope of the aforementioned empirical literature we examine the presence of nonlinear effects in our model. As far as we are concerned, the only study from the empirical literature on political economy of the social security that considers the non-linear effect of ageing on socialspending patterns is the one undertaken by Lindert (1996).

First, in order to check for non-linear effects, we test which specification fits our data better with the help of simple scatter-plots of Figure 3. We check for non-linear effects concluding that the cubic regression model fits the data better than the quadratic or the linear one.

\footnotetext{
${ }^{34}$ Definitions and sources of the variables can be found in Table 9, Appendix B.

${ }^{35}$ The former is a variable that takes values that represent five different types of government starting from the strongest type $(=1$, single party majority) to the weakest type $(=5$, multi-party minority). The latter represents the ideological spectrum of the government cabinet (also known as Schmidt-Index) and goes from the hegemony of right-wing and centre parties $(=1)$ to the hegemony of social-democratic and other left-wing parties $(=5)$.
} 
Table 6: Baseline Model

\begin{tabular}{lllllll}
\hline \hline & TPS & PSPR & TPS & PSPR & TPS & PSPR \\
\hline ODR & $(1)$ & $(2)$ & $(3)$ & $(4)$ & $(5)$ & $(6)$ \\
& $0.209^{* * *}$ & $-0.168^{*}$ & & & & \\
ODR $(+55)$ & $(0.031)$ & $(0.076)$ & & & & \\
& & & $0.122^{* *}$ & -0.0983 & & \\
PRODR & & $(0.033)$ & $(0.057)$ & & \\
& & & & & -0.0365 & $-0.201^{* *}$ \\
\hline Controls & Yes & Yes & Yes & Yes & Yes & Yes \\
\hline Country \& Time FE & Yes & Yes & Yes & Yes & Yes & Yes \\
\hline Obs & 152 & 152 & 152 & 152 & 152 & 152 \\
\hline Adj. R ${ }^{2}$-within & 0.692 & 0.920 & 0.665 & 0.919 & 0.615 & 0.924 \\
\hline \hline
\end{tabular}

Note: Fixed effects regressions with robust standard errors reported in parentheses, ${ }^{* * *} p<0.001$, ${ }^{* *} p<0.01,{ }^{*} p<0.05, \dagger p<0.10$. Pension spending per retiree (PSPR) and GDPpc are measured in $\$$ 1000. TPS: Total pensions spending. (PR)ODR[+55]: (Projected) Old dependency ratio [the ratio of the population above 55 years old over the working-age population]. Constant term is included but not reported.

Figure 3: As we can see from the scatter plots of pension spending per retiree (PSPR) with old dependency ratio $(O D R)$ (scatter plot, a) and old dependency ratio for the population over 55 years old $(O L D+55)$ (scatter plot, b), the best fit is the cubic model.

(a) PSPR and ODR
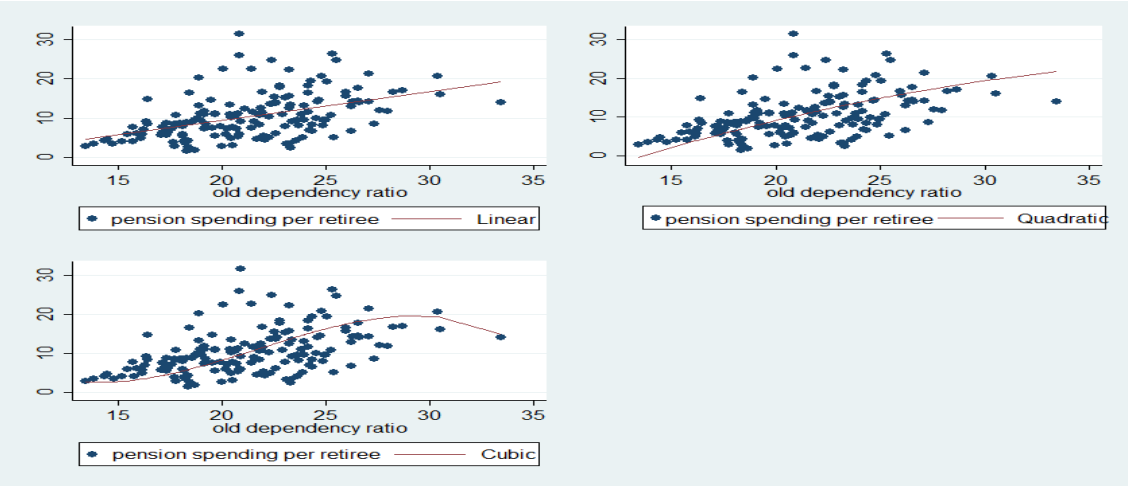

(b) PSPR and ODR $(+55)$
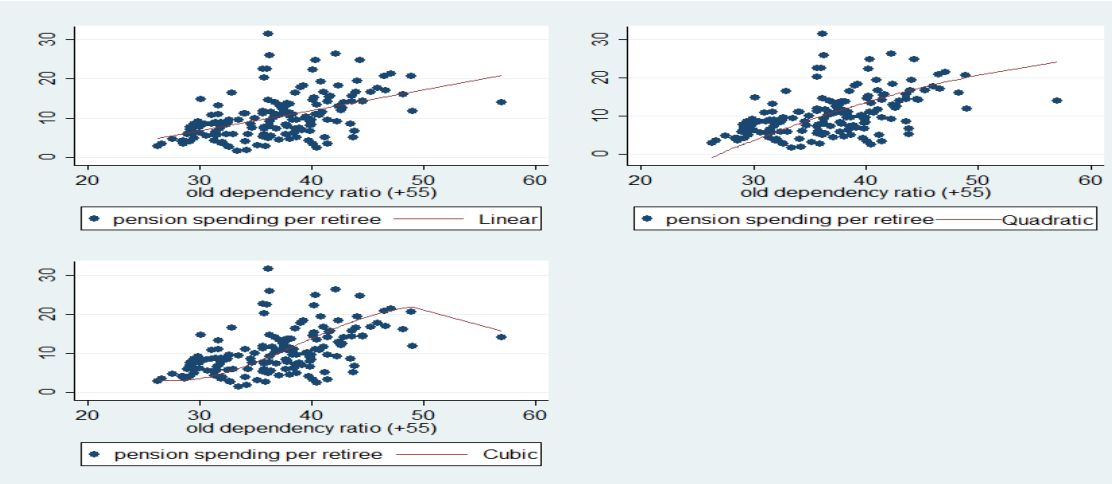
Table 7: Non-linear specification of the demographic variables

\begin{tabular}{lllll}
\hline \hline & TPS & PSPR & TPS & PSPR \\
\hline & $(1)$ & $(2)$ & $(3)$ & $(4)$ \\
\hline ODR & -1.422 & $-5.743^{* *}$ & & \\
& $(0.914)$ & $(1.980)$ & & \\
$(\text { ODR })^{2}$ & 0.0691 & $0.229^{*}$ & & \\
& $(0.042)$ & $(0.088)$ & & \\
$($ ODR $) 3$ & -0.000935 & $-0.00300^{*}$ & & $-6.764^{*}$ \\
& $(0.001)$ & $(0.001)$ & & $(2.477)$ \\
ODR $(+55)$ & & & -0.432 & $(1.162)$ \\
& & & 0.00892 & $0.156^{*}$ \\
$(\text { ODR }(+55))^{2}$ & & & $(0.029)$ & $(0.061)$ \\
& & & -0.0000326 & $-0.00118^{*}$ \\
$(\text { ODR }(+55))^{3}$ & & & $(0.000)$ & $(0.000)$ \\
\hline Controls & Yes & Yes & Yes & Yes \\
\hline Country \& Time FE & Yes & Yes & Yes & Yes \\
\hline Obs & 152 & 152 & 152 & 152 \\
\hline Adj. R ${ }^{2}$-within & 0.697 & 0.928 & 0.677 & 0.933 \\
\hline \hline
\end{tabular}

Note: Fixed effects regressions with robust standard errors reported in parentheses, ${ }^{* * *} p<0.001,{ }^{* *} p<0.01,{ }^{*} p<0.05, \dagger p<0.10$. Pension spending per retiree (PSPR) and GDPpc are measured in \$1000. TPS: Total pensions spending. ODR[+55]: Old dependency ratio [the ratio of the population above 55 years old over the working-age population]. Constant term is included but not reported.

As it is obvious from the Table 7 , the effect of the population ratios (ODR and ODR $(+55)$ ) on retirement spending per retiree is non-linear (reg. 2 and 4, respectively). More specifically, the effect of the ODR on retirement spending per retiree can be analysed through its cubic regression model. A change in the ODR from 13 to $14 \%$ has a negative impact (-1.201) on pension expenditure, ceteris paribus. ${ }^{36}$ The negative impact of the ODR on generosity of the system can be observed until the level where the ODR $=23 \%$; however, the magnitude of the effect decreases gradually from 13 to 23. This direction of the effect is clearly in favour of the "fiscal leakage" hypothesis; the generosity of the PAYG pension system decreases with a larger share of elderly people in society. As we can observe after this point $(\mathrm{ODR}=23 \%$ ), a change in the old dependency ratio from 23 to 24 has a positive effect on pension and this effect holds until the point where the ODR $=28 \%$. The demographic transition in this range (23 to 28 ) has a positive effect on pension generosity and that is in favour of the "elderly power" hypothesis. However, beyond the point where the old dependency ratio is 28 , we observe again the negative impact of a change in the ODR on pension generosity, and the magnitude of the effect increases as the old dependency ratio increases, even beyond our data range. The intuition behind these results can be as follows. The initial increase in the number of retirees puts pressure on the pension system and therefore has a negative effect on it. However, as the old dependency ratio grows, it reaches a certain point $(\mathrm{ODR}=23 \%)$ where the elderly acquire

\footnotetext{
${ }^{36}$ The range of the variable old dependency ratio in our data is from 13 to $33 \%$ and for ODR $(+55)$ is from 26 to 57 $\%$, respectively.
} 
considerable political power in order to influence the government to favour more generous pensions. It seems that they manage to cancel out the negative effect on the PAYG pension system from the increasing number of old people. Nevertheless, after a certain point (ODR=28 \%), the number of retirees is too big to be counterbalanced by the political power of the elderly. Similar interpretation applies to the other demographic proxy variable $(\mathrm{ODR}(+55))$.

Hence, our empirical findings provide an indication that population ageing has a non-linear effect on pension expenditure per retiree and therefore both effects are present. Thus, the outcome and the strength of both effects depend on the proportion of old people. Hence, when the old dependency ratio (or ODR $(+55)$ ) is at a very high level, the "elderly power" effect is dominated by the "fiscal leakage" effect. 


\section{B Graphs, Tables, Data Sources}

Figure 4: In this graph we can observe the across time parallel trend for education and pension spending. Education spending per student and pension spending per retiree are measured in \$1000.

Australia
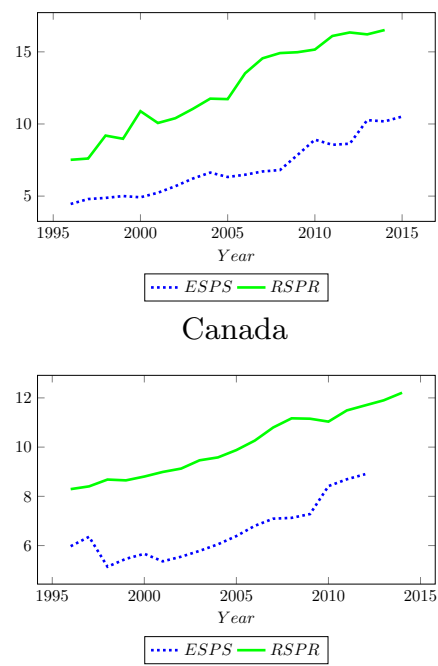

Estonia

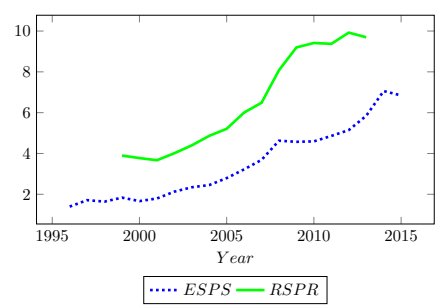

Germany

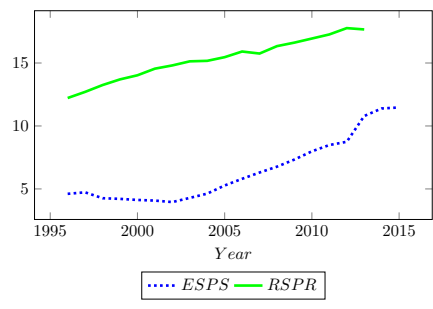

Iceland

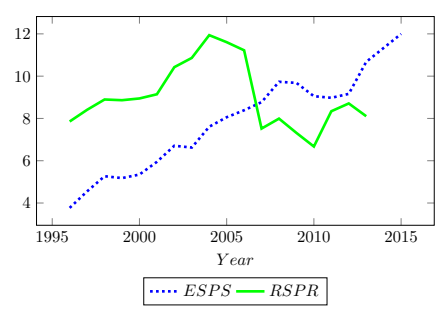

Austria

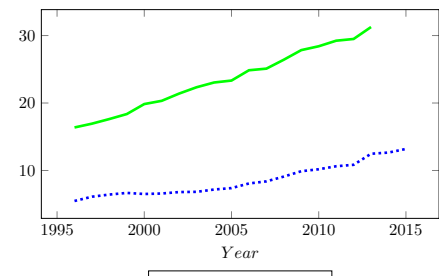

…ESPS-RSPR

Czech Republic

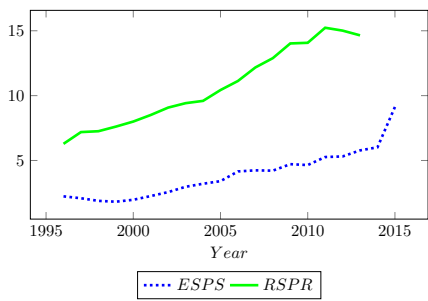

Finland

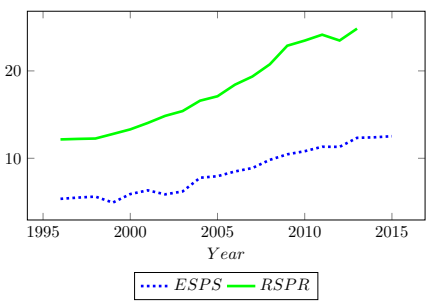

Greece

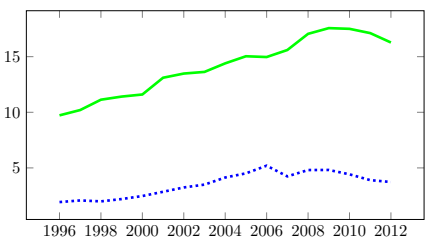

199619982000200220042006200820102012

$$
\text { …ESPS-RSPR }
$$

Ireland

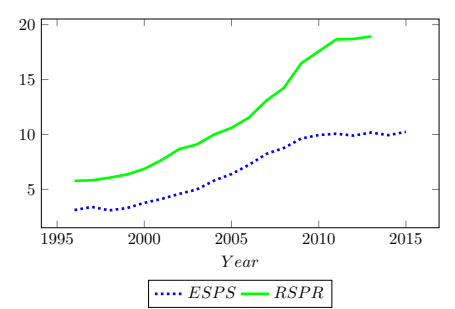

Belgium
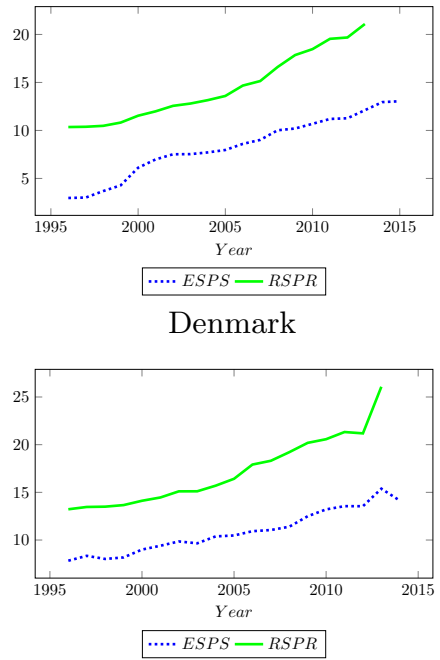

France
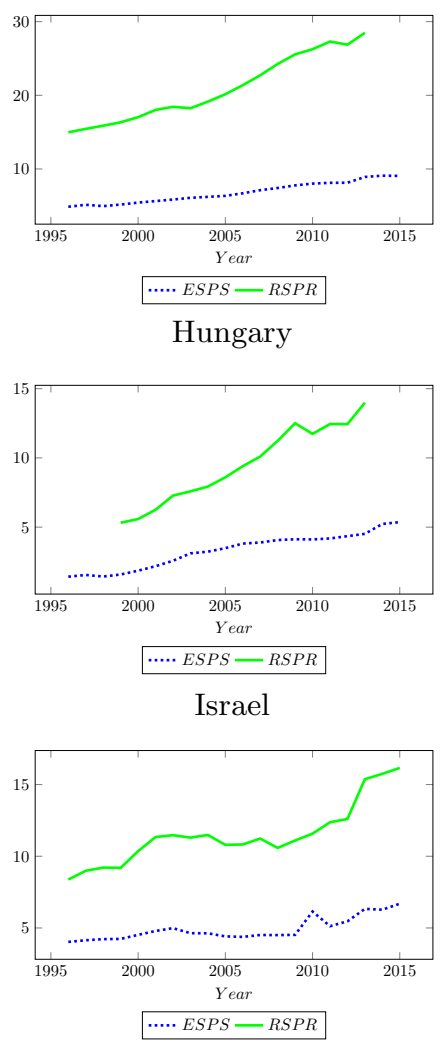
Figure 4: Continuation
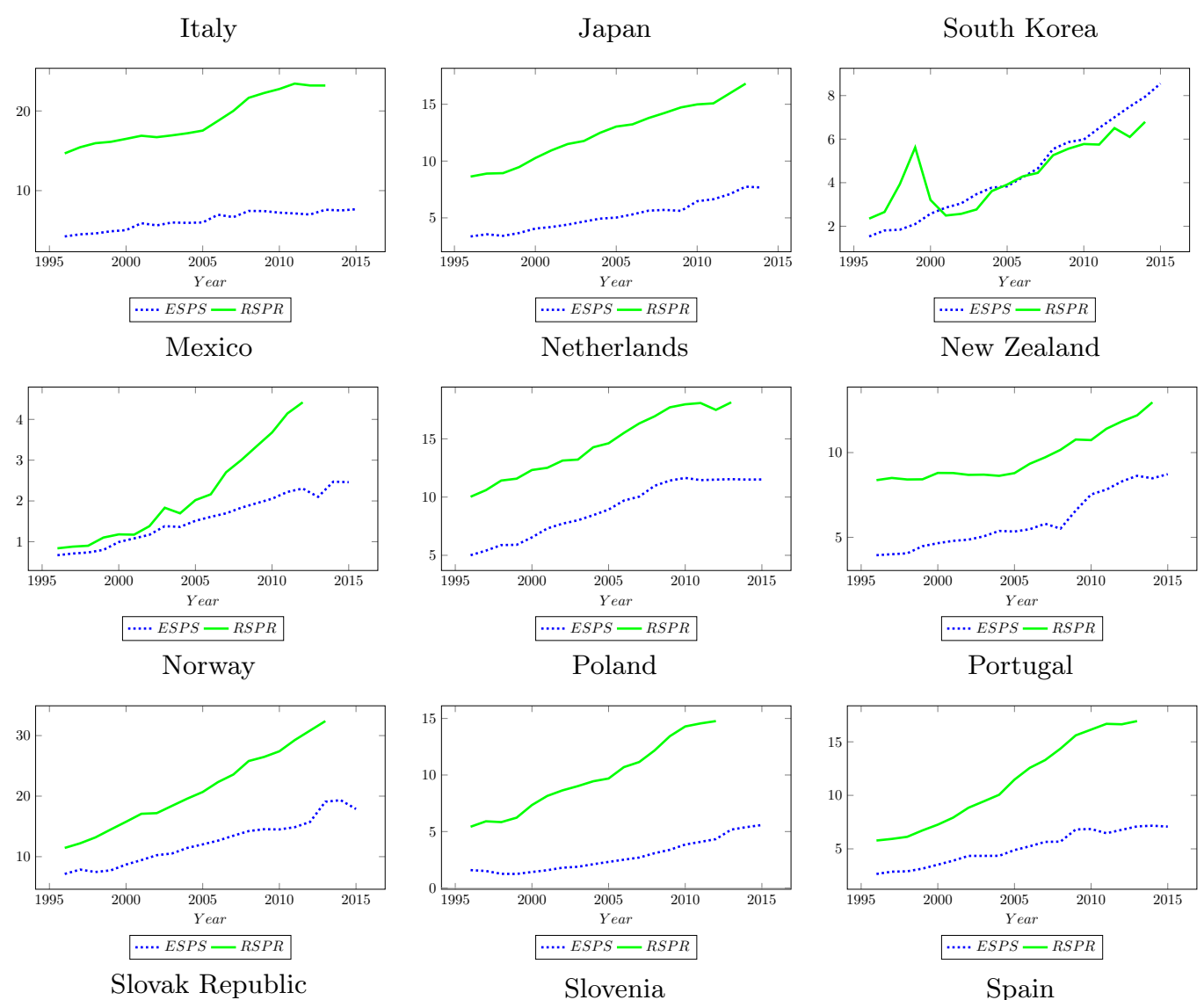

Slovak Republic

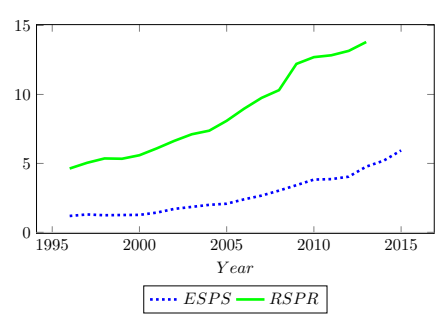

Slovenia
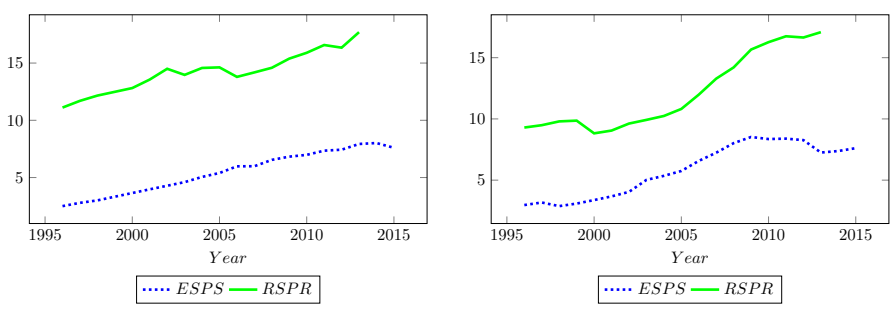

Sweden

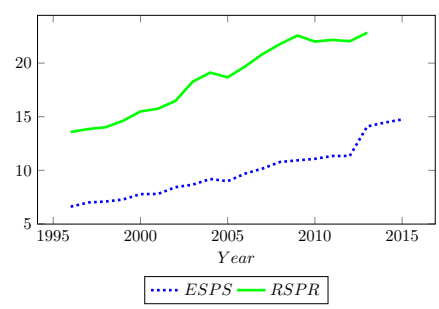

Switzerland

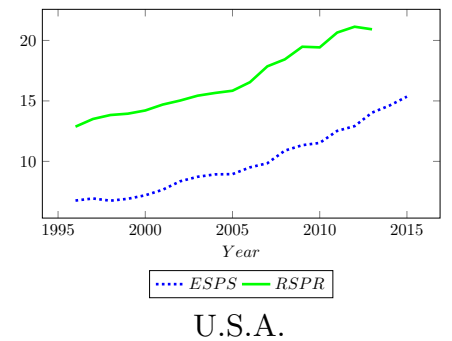

U.K.
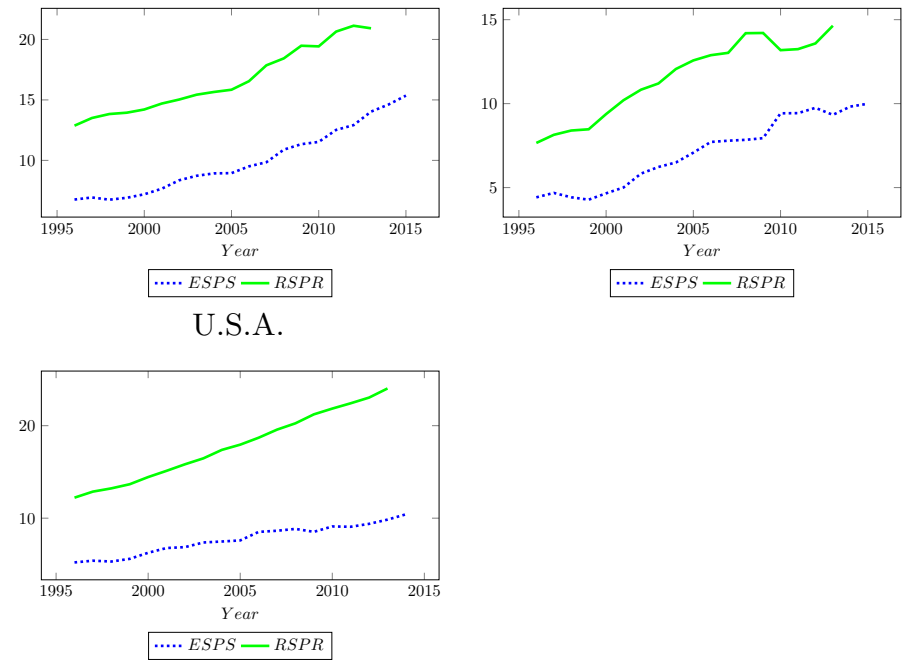
Table 8: Panel data descriptive statistics

\begin{tabular}{lllllll}
\hline \hline Variable & & Mean & Std. Dev. & Min & Max & Observations \\
\hline TES & overall & 5.3710 & 1.1699 & 2.9887 & 8.8069 & $\mathrm{~N}=609$ \\
& between & & 1.1026 & 3.3789 & 8.2799 & $\mathrm{n}=31$ \\
& within & & .4619 & 2.7280 & 6.9282 & $\mathrm{~T}=19.65$ \\
ESPS & overall & \multirow{2}{*}{6.3954} & 3.2454 & .6691 & 19.3315 & $\mathrm{~N}=606$ \\
& between & & 2.5710 & 1.0988 & 13.2837 & $\mathrm{n}=31$ \\
& within & & 2.0224 & 1.3138 & 10.3288 & $\mathrm{~T}=19.55$ \\
TPS & overall & \multirow{2}{*}{6.8624} & 2.8467 & .5 & 13.72 & $\mathrm{~N}=554$ \\
& between & & 2.7724 & .9411 & 12.0233 & $\mathrm{n}=31$ \\
& within & & .7772 & 4.1624 & 10.3689 & $\mathrm{~T}$-bar $=17.87$ \\
PSPR & overall & \multirow{2}{*}{13.2055} & 5.7301 & .8376 & 32.3935 & $\mathrm{~N}=554$ \\
& between & & 4.8821 & 2.1447 & 23.4547 & $\mathrm{n}=31$ \\
& within & & 3.1507 & 3.6482 & 24.5951 & $\mathrm{~T}$-bar $=17.87$ \\
\hline \hline
\end{tabular}

Note: ESPS and PSPR are measured in $\$ 1000$

Figure 5: In those graphs we can see the difference between the variation of the total education and pension spending. Unlike the pensions that are clustered over periods of 4 to 5 years (period needed for a pension reform), education seems to vary on an almost annual basis.

(a) Total education spending over time

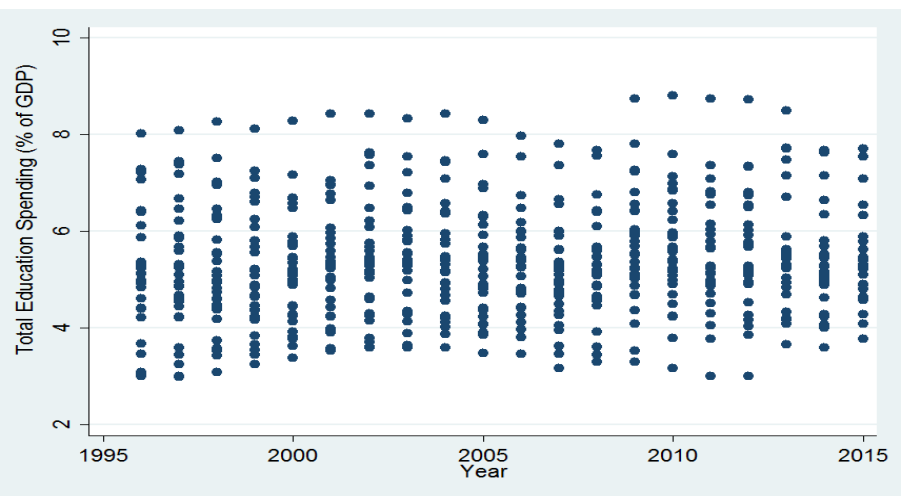

(b) Total pension spending over time

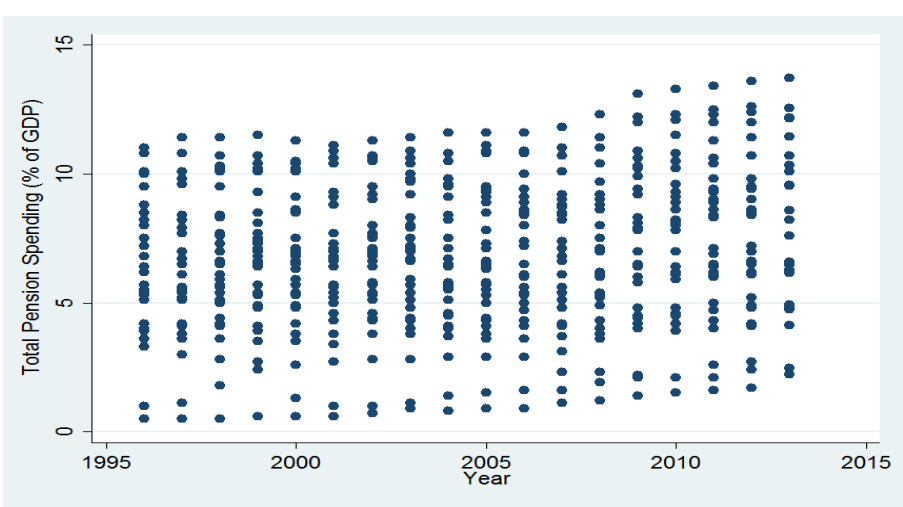


Table 9: Data Definitions and Sources

\begin{tabular}{|c|c|}
\hline Variable & Definition and Source \\
\hline TES & $\begin{array}{l}\text { Total Education Spending as \% of GDP. Source: UNESCO (2015), http: } \\
\text { //data.uis.unesco.org/Index.aspx?DataSetCode=EDULIT_DS }\end{array}$ \\
\hline ESPS & $\begin{array}{l}\text { Education Spending per Student. Source: Our own calculation using } \\
\text { Total Education Spending as a percentage of GDP, GDP PPP (US \$ } \\
\text { current) and the population of the official age for education. }\end{array}$ \\
\hline TPS & $\begin{array}{l}\text { Total Pension Spending as percentage of GDP. Source: OECD (2015) } \\
\text { Social Expenditure-Aggregate data, http://stats.oecd.org/Index.aspx? } \\
\text { DataSetCode=SOCX_AGG }\end{array}$ \\
\hline PSPR & $\begin{array}{l}\text { Pensions Spending per Retiree. Source: Our own calculations using } \\
\text { Total Pension Spending as } \% \text { of GDP,GDP PPP (US } \$ \text { current) and the } \\
\text { number of people over } 65 \text { years old. }\end{array}$ \\
\hline $\mathrm{ODR}(+55)$ & $\begin{array}{l}\text { Population over } 55 \text { years old as a proportion of the working age pop- } \\
\text { ulation. Source: OECD (2015) Demography and Population, http: } \\
\text { //stats.oecd.org/\# }\end{array}$ \\
\hline ODR & $\begin{array}{l}\text { Old Dependency Ratio. Population over } 65 \text { years old as proportion of } \\
\text { the working age population (15-64). Source: OECD (2015) Demography } \\
\text { and Population, http://stats.oecd.org/\# }\end{array}$ \\
\hline PRODR & $\begin{array}{l}\text { Projected Old Dependency Ratio. Source: OECD (2015), http://stats. } \\
\text { oecd.org/ Historical population data and projections. }\end{array}$ \\
\hline GDPpc & $\begin{array}{l}\text { GDP per capita PPP (US current \$) Source: OECD (2015) https:// } \\
\text { stats.oecd.org/index.aspx?queryid }=60702 \#\end{array}$ \\
\hline GDP Growth & $\begin{array}{l}\text { Growth of real GDP, percentage change from previous year. Source: } \\
\text { World Bank (2015), http://databank.worldbank.org/data/ }\end{array}$ \\
\hline Interest rate & $\begin{array}{l}\text { Long-term interest rate on government bonds. Source: Armingeon } \\
(2012) \text { http://www.cpds-data.org/ }\end{array}$ \\
\hline Openc & $\begin{array}{l}\text { Openness of the economy, measured as total trade (sum of imports and } \\
\text { exports) as a percentage of GDP, in current prices. Source: Armingeon } \\
\text { (2012) http://www.cpds-data.org/ }\end{array}$ \\
\hline Unemp & $\begin{array}{l}\text { Unemployment rate as a percentage of civilian labor force. Source: } \\
\text { Armingeon (2012) http://www.cpds-data.org/ }\end{array}$ \\
\hline Union Density & $\begin{array}{l}\text { Ratio of wage and salary earners that are trade union members, divided } \\
\text { by the total number of wage and salary earners. Source: OECD (2015), } \\
\text { http://stats.oecd.org/Index.aspx?DataSetCode=UN_DEN }\end{array}$ \\
\hline G.T. & $\begin{array}{l}\text { Type of Government. Source: Armingeon (2012) http://www.cpds-data. } \\
\text { org/ }\end{array}$ \\
\hline G.P. & $\begin{array}{l}\text { Cabinet composition (Schmidt-Index). Ideology of the government } \\
\text { parties(-ies). Source: Armingeon (2012) http://www.cpds-data.org/ }\end{array}$ \\
\hline
\end{tabular}


Table 9 (continuation): Data Definitions and Sources

\begin{tabular}{|c|c|}
\hline Variable & Definition and Sources \\
\hline Tax Revenue & $\begin{array}{l}\text { Tax revenue as \% of GDP. Source: OECD (2015), http://stats.oecd.org/ } \\
\text { viewhtml.aspx?datasetcode=REV\&lang=en\# }\end{array}$ \\
\hline Tot & $\begin{array}{l}\text { Total Social Expenditure. Source: OECD (2015) Social Expenditure- } \\
\text { Aggregate data, http://stats.oecd.org/Index.aspx?DataSetCode= } \\
\text { SOCX_AGG }\end{array}$ \\
\hline MYS & $\begin{array}{l}\text { Mean years of schooling. Source: UN (2014), http://hdr.undp.org/en/ } \\
\text { dataviz-competition }\end{array}$ \\
\hline Left & $\begin{array}{l}\text { Dummy variable for Left ideology of the government. Source: Armin- } \\
\text { geon (2012). }\end{array}$ \\
\hline GI & $\begin{array}{l}\text { Globalization Index. Source: KOF, ETH Zurich, http://globalization. } \\
\text { kof.ethz.ch/ }\end{array}$ \\
\hline VAI & $\begin{array}{l}\text { Voice and Accountability Index. Source: Worldwide Governance Indica- } \\
\text { tors (WGI) project, http://info.worldbank.org/governance/wgi/index. } \\
\text { aspx\#home }\end{array}$ \\
\hline EFI & $\begin{array}{l}\text { Economic Freedom Index. Source: Heritage Foundation Research Insti- } \\
\text { tute/Wall Street Journal, http://www.heritage.org/index/ }\end{array}$ \\
\hline duc & $\begin{array}{l}\text { Population of the official age for education in total population. } \\
\text { Source: UNESCO (2015) Education, http://data.uis.unesco.org/Index. } \\
\text { aspx?DataSetCode=EDULIT_DS }\end{array}$ \\
\hline Fertility & $\begin{array}{l}\text { Fertility rate. Source: OECD (2015) Demography, https://data.oecd. } \\
\text { org/pop/fertility-rates.htm }\end{array}$ \\
\hline PPES & $\begin{array}{l}\text { Education spending by level of education as percentage of GDP, } \\
\text { pre-primary (PPES), primary (PES), secondary (SES) and ter- } \\
\text { tiary (TERES). Source: UNESCO (2015), http://data.uis.unesco.org/ } \\
\text { ?queryid=181 }\end{array}$ \\
\hline ap & $\begin{array}{l}\text { Population of the official age for education in total population by level of } \\
\text { education, pre-primary (ppoap), primary (poap), secondary (soap) and } \\
\text { tertiary (toap). Source: UNESCO (2015), http://data.uis.unesco.org/ } \\
\text { ?queryid=181 }\end{array}$ \\
\hline
\end{tabular}




\section{References}

Baltagi, Badi H., and Qi Li. 1991. "A joint test for serial correlation and random individual effects." Statistics and Probability Letters 11 (3): 277-280.

. 1995. "Testing AR(1) against MA(1) disturbances in an error component model." Journal of Econometrics 68 (1): 133-151.

Baum, Christopher F. 2001. "Residual diagnostics for cross-section time series regression models." The Stata Journal 1 (1): 101-104.

Becker, Gary S., and Kevin M. Murphy. 1988. "The Family and the State." The Journal of Law E Economics 31 (1): 1-18.

Becker, Gary S., Kevin M. Murphy, and Robert Tamura. 1990. "Human Capital, Fertility, and Economic Growth." Journal of Political Economy 98 (5): 12-37.

Boadway, Robin W., and David E. Wildasin. 1989. "A Median Voter Model of Social Security." International Economic Review 30 (2): 307-328.

Boldrin, Michele. 1992. "Public Education and Capital Accumulation." C.M.S.E.M.S. Discussion Paper No. $101 \%$.

Boldrin, Michele, and Ana Montes. 2005. "The Intergenerational State Education and Pensions." Review of Economic Studies 72 (3): 651-664.

Boldrin, Michele, and Aldo Rustichini. 2000. "Political Equilibria with Social Security." Review of Economic Dynamics 3 (1): 41-78.

Borge, Lars-Erik, and Jørn Rattsø. 2008. "Young and Old Competing for Public Welfare Services." CESifo Working Paper Series No. 2223.

Breusch, T.S., and A.R. Pagan. 1980. "The Lagrange Multiplier Test and Its Applications to Model Specification in Econometrics." Review of Economic Studies 47 (1): 239-253.

Breyer, Friedrich. 1994. "The political economy of intergenerational redistribution." European Journal of Political Economy 10 (1): 61-84.

Breyer, Friedrich, and Ben Craig. 1997. "Voting on social security: Evidence from OECD countries." European Journal of Political Economy 13 (4): 705-724.

Breyer, Friedrich, and Klaus Stolte. 2001. "Demographic change, endogenous labor supply and the political feasibility of pension reform." Journal of Population Economics 14 (3): 409-424.

Browning, Edgar K. 1975. "Why the Social Insurance Budget Is Too Large in a Democracy." Economic Inquiry 13 (3): 373-388.

Brunner, Eric, and Ed Balsdon. 2004. "Intergenerational conflict and the political economy of school spending." Journal of Urban Economics 56 (2): 369-388.

Busemeyer, Marius R. 2007. "Determinants of public education spending in 21 OECD democracies, 1980-2001." Journal of European Public Policy 14 (4): 582-610.

Cameron, A Colin, and Pravin K Trivedi. 2010. Microeconometrics Using Stata: Revised Edition. A Stata College Station, Texas: Stata Press. 
Castles, Francis G. 2004. The Future of the Welfare State: Crisis Myths and Crisis Realities. Oxford: Oxford University Press.

Castles, Francis G. 1989. "Explaining public education expenditure in OECD nations." European Journal of Political Research 17 (4): 431-448.

— 1994. "On religion and public policy: Does Catholicism make a difference?" European Journal of Political Research 25 (1): 19-40.

Cattaneo, Alejandra M., and Stefan C. Wolter. 2009. "Are the elderly a threat to educational expenditures?" European Journal of Political Economy 25 (2): 225-236.

Choi, Ki-Hong, and Sungwhee Shin. 2015. "Population aging, economic growth, and the social transmission of human capital: An analysis with an overlapping generations model." Economic Modelling 50 (nov): 138-147.

De La Croix, David, and Matthias Doepke. 2009. "To Segregate or to Integrate: Education Politics and Democracy." Review of Economic Studies 76 (2): 597-628 (apr).

Disney, Richard. 2007. "Population ageing and the size of the welfare state: Is there a puzzle to explain?" European Journal of Political Economy 23 (2): 542-553.

Doepke, Matthias, and Michèle Tertilt. 2016. "Families in Macroeconomics." NBER Working Paper No.22068.

Downs, Anthony. 1957. "An Economic Theory of Political Action in a Democracy." Journal of Political Economy 65 (2): 135-150.

Driscoll, John C, and Aart C Kraay. 1998. "Consistent Covariance Matrix Estimation with Spatially Dependent Panel Data." Review of Economics and Statistics 80 (4): 549-560.

Esping-Andersen, Gøsta, and Francesco C Billari. 2015. "Re-theorizing Family Demographics." Population and Development Review 41 (1): 1-31.

Fehr, Ernst, and Klaus M. Schmidt. 2006. "The Economics of Fairness, Reciprocity and Altruism Experimental Evidence and New Theories." Chapter 8 of Handbook of the Economics of Giving, Altruism and Reciprocity, edited by Serge-Christophe Kolm and Jean Mercier Ythier, Volume 1. Amsterdam: Amsterdam: North-Holland.

Frees, Edward W. 1995. "Assessing cross-sectional correlation in panel data." Journal of Econometrics 69 (2): 393-414.

Galasso, Vincenzo, and Paola Profeta. 2002. "The political economy of social security: a survey." European Journal of Political Economy 18 (1): 1-29.

Galor, Oded, and David N. Weil. 1996. "The Gender Gap, Fertility, and Growth." American Economic Review 86 (3): 374-387.

- 2000. "Population, Technology, and Growth: From Malthusian Stagnation to the Demographic Transition and beyond." The American Economic Review 90 (4): 806-828.

Gradstein, Mark, and Michael Kaganovich. 2004. "Aging population and education finance." Journal of Public Economics 88 (12): 2469-2485. 
Grob, Ueli, and Stefan C. Wolter. 2007. "Demographic change and public education spending: A conflict between young and old?" Education Economics 15 (3): 277-292.

Harris, Amy Rehder, William N Evans, and Robert M Schwab. 2001. "Education spending in an aging America." Journal of Public Economics 81 (3): 449-472.

Hausman, Jerry A. 1978. "Specification Tests in Econometrics." Econometrica 46 (6): 1251-1271.

Hess, Moritz, Elias Nauman, and Leander Steinkopf. 2017. "Population Ageing, the Intergenerational Conflict, and Active Ageing Policies - a Multilevel Study of 27 European Countries." Journal of Population Ageing 10 (1): 11-23 (mar).

Hoechle, Daniel. 2007. "Robust standard errors for panel regressions with cross-sectional dependence." The Stata Journal 7 (3): 281-312.

Hollanders, D.A., and F. Koster. 2012. "The Graying of the Median Voter." Discussion Paper 2012-061.

Jäger, Philipp, and Torsten Schmidt. 2016. "The political economy of public investment when population is aging: A panel cointegration analysis." European Journal of Political Economy 43 (jun): $145-158$.

Kemnitz, Alexander. 2000. "Social security, public education, and growth in a representative democracy." Journal of Population Economics 13 (3): 443-462.

Konrad, Kai A. 1995. "Social security and strategic inter-vivos transfers of social capital." Journal of Population Economics 8 (3): 315-326.

Krieger, Tim, and Jens Ruhose. 2013. "Honey, I shrunk the kids' benefits - revisiting intergenerational conflict in OECD countries." Public Choice 157 (1-2): 115-143.

Ladd, Helen F., and Sheila E. Murray. 2001. "Intergenerational conflict reconsidered: county demographic structure and the demand for public education." Economics of Education Review 20 (4): $343-357$.

Laferrère, Anne, and François-Charles Wolff. 2006. "Microeconomic models of family transfers." Chapter 13 of Handbook of the Economics of Giving, Altruism and Reciprocity, edited by SergeChristophe Kolm and Jean Mercier Ythier, Volume 2. Amsterdam: Amsterdam: North-Holland.

Lancia, Francesco, and Alessia Russo. 2016. "Public Education and Pensions in Democracy: a Political Economy Theory." Journal of the European Economic Association 14 (5): 1038-1073.

Lindert, Peter H. 1996. "What Limits Social Spending?" Explorations in Economic History 33 (1): $1-34$.

Michailidis, Gianko, and Concepció Patxot. 2018. "Political viability of public pensions and education. An empirical application." Applied Economics Letters 26 (03): 245 - 249.

Michel, Philippe, Emmanuel Thibault, and Jean-Pierre Vidal. 2006. "Intergenerational altruism and neoclassical growth models." Chapter 15 of Handbook of the Economics of Giving, Altruism and Reciprocity, edited by Serge-Christophe Kolm and Jean Mercier Ythier, Volume 2. Amsterdam: Amsterdam: North-Holland. 
Morales, Agustín Molina, Ignacio Amate Fortes, and Almudena Guarnido. 2013. "Institutions and Public Expenditure on Education in OECD Countries." Hacienda Pública Española/Review of Public Economics 204 (1): 67-84.

Mulligan, Casey, and Xavier Sala-i Martin. 1999. "Gerontocracy, Retirement, and Social Security." NBER Working Paper No. 7119.

Persson, Torsten., and Guido Enrico Tabellini. 2000. Political economics : explaining economic policy. Cambridge, MA: MIT Press.

Pesaran, M. H. 2004. "General Diagnostic Tests for Cross Section Dependence in Panels." Cambridge, MA: Working Papers in Economics No.0435, pp. 101-104.

Pogue, Thomas F., and L. G. Sgontz. 1977. "Social security and investment in human capital." National Tax Journal 30:157-169.

Poterba, James M. 1998. "Demographic Change, Intergenerational Linkages, and Public Education." American Economic Review 88 (2): 315-320.

Poterba, James M. 1997. "Demographic Structure and the Political Economy of Public Education." Journal of Policy Analysis and Management 16 (1): 48-66.

Rangel, Antonio. 2003. "Forward and Backward Intergenerational Goods: Why Is Social Security Good for the Environment?" American Economic Review 93 (3): 813-834.

Razin, Assaf, and Efraim Sadka. 2007. "Aging population: The complex effect of fiscal leakages on the politico-economic equilibrium." European Journal of Political Economy 23 (2): 564-575.

Razin, Assaf, Efraim Sadka, and Phillip Swagel. 2002. "The Aging Population and the Size of the Welfare State." Journal of Political Economy 110 (4): 900-918.

Roubini, Nouriel, and Jeffrey Sachs. 1989. "Government Spending and Budget Deficits in the Industrial Countries." Economic Policy 4 (8): 99-132.

Shelton, Cameron A. 2008. "The aging population and the size of the welfare state: Is there a puzzle?" Journal of Public Economics 92 (3-4): 647-651.

Tabellini, Guido. 2000. "A Positive Theory of Social Security." Scandinavian Journal of Economics 102 (3): $523-545$.

Tepe, Markus, and Pieter Vanhuysee. 2009. "Are Aging OECD Welfare States on the Path to Gerontocracy? Evidence from 18 Democracies, 1980-2002." Journal of Public Policy 29 (1): $1-28$. 